\title{
THE FAILURE OF UNIVERSAL THEORIES OF TORT LAW
}

\author{
James Goudkamp* and John Murphy ${ }^{* *}$
}

Many scholars have offered theories that purport to explain the whole of the law of torts. At least some of these theories do not seem to be specific to a single jurisdiction. Several appear to endeavour to account for tort law in at least the major common law jurisdictions, or even throughout the common law world. These include Ernest Weinrib’s corrective justice theory, Robert Stevens’s rights theory, and Richard Posner's economic theory. This article begins by explaining why it is appropriate to understand these three theories as universal theories of tort law, which is an important feature of these theories that has not hitherto been properly appreciated. This explanation draws upon various overt claims (or other strong intimations) made by the theorists themselves to the effect that this is how their respective accounts should be understood. The article then proceeds to test these theories, all of which are leading accounts of tort law, against the evidence in Australia, Canada, the United Kingdom and the United States. Not all of these theories have received a proper airing in these major common law jurisdictions, which is a gap in the literature that this article seeks to fill. The parts of tort law on which we focus are (1) the breach element of the action in negligence, (2) the law that determines when a duty of care will be owed in respect of pure economic

\footnotetext{
Fellow, Keble College, Oxford; Associate Professor, Oxford Law Faculty; Academic Fellow, Inner Temple; Senior Honorary Research Fellow, Faculty of Law, University of Western Australia, Honorary Principal Fellow, School of Law, University of Wollongong, barrister, 7 King's Bench Walk. Email: james.goudkamp@law.ox.ac.uk. We are most grateful to Ellen Bublick, Peter Cane, Steve Hedley, William Lucy, Nicholas McBride, Jason Neyers and Dan Priel for their valuable comments on drafts of this article. Jodi Gardner and Mengfei Ying provided us with excellent research assistance.

Professor, Law School, Lancaster University.
} 
loss, (3) the law that governs the availability of punitive damages, (4) the defense of illegality and (5) the rule in Rylands v. Fletcher and its descendants. The article concludes that none of the theories is a satisfactory universal account of tort law. All of them suffer from significant problems of fit in that they cannot accommodate (often even approximately) the areas of law that we discuss. While all of the theories contain valuable insights, they fall well short of accomplishing that which they are held out as providing. In the course of this analysis, the article explains why this is an appropriate line of criticism and identifies the degree of lack of fit that we regard as being "significant”.

\section{INTRODUCTION}

It is currently fashionable to offer accounts of tort law that purport to explain it in its entirety. Every few years, a new theoretical model appears on the market, and is touted as the best explanation on offer. Take, for example, Ernest Weinrib's The Idea of Private Law. ${ }^{1}$ Although this book is addressed to private law generally, ${ }^{2}$ it quickly emerges that Weinrib’s main mission is "to understand tort law". ${ }^{3}$ His most fundamental contention is that "Tort liability reflects corrective justice", ${ }^{4}$ and much of Weinrib’s book is an attempt to demonstrate "the immanence of corrective justice in tort law". ${ }^{5}$ For instance, in Chapter 6, Weinrib takes his readers to features of "negligence liability [that] illustrate... the formalist idea that corrective justice is immanent within a sophisticated system of private law". ${ }^{6}$ In Chapter 7 ,

\footnotetext{
Ernest J. Weinrib, The Idea of Private Law (1995).

Id. at 20.

Id. at 3.

Id. at 134 .

Id. at 171.

Id. at 146 .
} 
Weinrib's goal is to prove that several of tort law doctrines that are generally thought to impose strict liability - a form of liability which Weinrib regards as inconsistent with corrective justice $^{7}$ - properly understood "are either extensions of fault liability or are ways in which the common law regulates the use of property in accordance with corrective justice". 8 The foregoing makes it explicit that Weinrib's overarching enterprise is to show that his corrective justice theory fits tort law.

More recently, Robert Stevens has offered an alternative explanatory account of tort law. In Torts and Rights, ${ }^{9}$ Stevens defends what he calls the "rights model” of tort law. According to this model, " $[\mathrm{t}]$ he law of torts is concerned with the secondary obligations generated by the infringement of primary rights. The infringement of rights, rather than the infliction of loss, is ... the gist of the law of torts”. ${ }^{10}$ In endeavoring "to show ... the truth" ${ }^{11}$ of this conception, Stevens deals systematically with numerous aspects of tort law. He argues that "the rightsbased model of the law of torts gives a better account of the common law as we find it"12 than other models. Stevens' claim therefore also is tort law conforms to his explanation of it.

As a final illustration of a writer who offers an explanatory theory of the whole of tort law, consider Richard Posner. In his Economic Analysis of Law, Posner contends that tort law (and the law generally) "is best (not perfectly) explained as a system for maximizing the wealth of society”. ${ }^{13}$ The opening sentence of The Economic Structure of Tort Law, which he coauthored with William Landes, claims that "the common law of torts is best explained as if the judges who created the law through decisions operating as precedents in later cases were

\footnotetext{
See Part IIE2 below.

8 Weinrib, supra note 1 , at 172.

9 Robert Stevens, Torts and Rights (2007).

10 Id. at 2 (footnote omitted).

11 Id. at 3.

12 Id. at 306.

13 Richard A. Posner, Economic Analysis of Law 25 (7th ed. 2007).
} 
trying to promote efficient resource allocation”. ${ }^{14}$ In these works (and in a staggering number of other contributions ${ }^{15}$ ) Posner draws attention to many aspects of tort law that he believes substantiate this claim.

The foregoing theorists all seek to explain tort law, as the quotations that we have supplied make abundantly clear. Whether or not they succeed in their endeavour is one of the most important questions in modern private law scholarship. In order to answer it, it is necessary to judge the theorists by reference to the body of law that they purport to explain. Does the explandum fit the explanans? It is necessary to ascertain, therefore, the legal system or systems with which the theorists in question are concerned As far as we can tell, this essential foundational work has not previously been performed.

Stevens is explicit regarding the jurisdictional scope of his theory. In Torts and Rights he writes: "I have focused on English cases for no better reason than that this is the material which I know best. However, the book would look much the same if I had primarily used the case law of any other common law jurisdiction". ${ }^{16}$ Stevens's claim that his theory is applicable to the common law world as a whole could scarcely be made more starkly, and he has elsewhere specifically attempted to extend it to Australia. ${ }^{17}$ By contrast, Weinrib does not make it crystal clear with which jurisdiction or jurisdictions he is concerned. Nowhere in The Idea of Private Law (or, so far as we can tell, in any of his many other relevant writings) does

14 William M. Landes \& Richard A. Posner, The Economic Structure of Tort Law 1 (1987).

15 See especially Richard A. Posner, A Theory of Negligence, 1 Journal of Legal Studies 29 (1972); Richard A. Posner, An Economic Theory of Intentional Torts, 1 International Review of Law \& Economics 127 (1981); William M. Landes \& Richard A. Posner, The Positive Economic Theory of Tort Law, 15 Ga. L. Rev. 851 (1980); William M. Landes \& Richard A. Posner, Causation in Tort Law, 12 Journal of Legal Studies 109 (1983); Richard A. Posner, Wealth Maximization and Tort Law: A Philosophical Inquiry, in Philosophical Foundations of Tort Law \& 4 (David G. Owen ed., 1995); Richard A. Posner, Instrumental and Noninstrumental Theories of Tort Law, 88 Ind. L. J. 469 (2013).

16 Stevens, supra note 9, at vii (emphasis added).

17 See Robert Stevens, The Divergence of the Australian and English Law of Torts, in Torts in Commercial Law $\S 3$ (Simone Degeling, James Edelman \& James Goudkamp eds., 2011). 
Weinrib state explicitly which countries he is discussing. ${ }^{18}$ Nonetheless, he seeks to support his theory by reference to many cases from Australia, Canada, the United Kingdom and the United States. The fact that he proceeds in this way strongly suggests that there is sufficient uniformity in the law in these jurisdictions to entitle him to draw on materials from any of them. And, given this assumption of substantial uniformity, he presumably also believes that the theory that he builds from the law in several jurisdictions must in turn apply to those jurisdictions. Overt confirmation that his theory is intended to be multi-jurisdictional in terms of its explanatory power appears in more recent work. Although he stops short of naming particular jurisdictions, Weinrib does state that his theory is applicable to "the private law relationships, as found in sophisticated legal systems”. ${ }^{19}$ At a minimum, then, this confirms the fact that Weinrib does not regard his theory as being confined to just one jurisdiction. Similar remarks can be made about Posner's work. In defending his economic explanation of tort law, Posner does not specify the full array of legal systems with which he is concerned. But, as with Weinrib, he tellingly often cites, without any words of qualification, decisions from the United States and the United Kingdom in support of his theory. ${ }^{20}$ In Law and Legal Theory in the UK and USA not only does Posner write that "in general English judges use their common sense effectively to approximate the results that an economic analyst would recommend", ${ }^{21}$ he also does nothing to distinguish the very many different common law jurisdictions found in the United States. He therefore clearly believes that the various systems

18 The same can also be said of Allan Beever, Rediscovering the Law of Negligence (2007), which offers an important elaboration of Weinrib's theory of tort law as applied to the tort of negligence.

19 Ernest J. Weinrib, Civil Recourse and Corrective Justice, 39 Fla. St. U. L. Rev. 273, 291 (2011).

20 For an illustration of Posner drawing on English authorities, see Landes and Posner, The Positive Economic Theory of Tort Law, supra note 15, where the landmark cases of Rylands v. Fletcher, LR 3 HL 330 (H.L.), Bolton v. Stone, AC 850 (H.L.), Blyth v. Birmingham Waterworks Co, 11 Exch 781 (1856), 156 Eng. Rep. 1047 (Exch 1856) and Paris v. Stepney Borough Council, AC 367 (H.L.) are cited.

21 Richard A. Posner, Law and Legal Theory in the UK and USA viii (1996). 
of tort law in the United States and in the United Kingdom are sufficiently similar that his economic theory is the best explanation available of tort law in both countries. ${ }^{22}$

As we have just noted, there is compelling evidence - in both the form of explicit claims and strong intimations - that Weinrib, Stevens and Posner are all concerned with tort law throughout the common law world. The daring nature of their claims is therefore hard to overstate. For, not only do they assert that they can account for all of tort law within a single jurisdiction $^{23}$ (itself a tall order), they claim also to have an explanation of tort law that is valid across all common law jurisdictions. ${ }^{24}$ They are offering, for want of a better description, universal theories of tort law. Their self-imposed task is to show that their respective models are the best available. The main purpose of this article is to test whether their theories can justifiably be rolled out throughout the common law world.

As is obvious from what we have said so far, the critique that we will employ in this article is one based on fit. We consider this to be an appropriate way of engaging with the theories. How could it not be given that the target theorists themselves, as we have shown, are fundamentally concerned to demonstrate that their accounts fit the law? Indeed, this type of criticism is entirely conventional. ${ }^{25}$ This does not mean, however, that this article adds nothing to existing treatments of the theories in question. Our enquiry is original in what it is testing, namely, whether the theories in issue constitute plausible universal theories of tort

22 See especially id. § 2. We are not alone in reading Posner in this way: see, e.g., Stevens, supra note 9, at 92.

23 It is axiomatic that none of these theorists is concerned with, for instance, just one tort or a handful of torts. Their accounts are addressed to tort law generally.

24 Some of these theorists may go further still by not merely claiming that they can account for tort law as it presently exists, but for all of its history. Consider, e.g., Stevens, supra note 17, at 39 where he asserts that the rights model of tort law has a longer history in the law than other models. Weinrib's claims seem not to be limited to common law jurisdictions: see the text accompanying supra note 19.

25 See, e.g., Andrew Burrows, Damages and Rights in Rights and Private Law § 10 (Andrew Robertson \& Donal Nolan eds., 2012) and John Murphy, Rights, Reductionism and Tort Law, 28 OJLS 393 (2008) (testing Stevens's rights theory against English law); Peter Cane, Corrective Justice and Correlativity in Private Law, 16 OJLS 471 (1996) (tackling Weinrib’s corrective justice theory in the context of English tort law); Jane Stapleton, Evaluating Goldberg and Zipursky's Civil Recourse Theory, 75 Fordham L. Rev. 1529 (2006) (arguing that the descriptive claims of Goldberg and Zipursky's theory are problematic when assessed against tort law in the United States). 
law. This article also makes a series of further substantial contributions to existing scholarship. We mention four further ways in which the analysis that we offer is important. First, revealing that the theories in question are universal in nature opens the door to a novel line of criticism, namely, the fact that the theorists in question, despite the universal nature of their accounts, frequently cherry pick rules that are consistent with their models and attempt to marginalise or simply ignore incompatible rules located in other jurisdictions. Secondly, many of the problems of fit that we canvass have not previously been identified, and certainly not treated at any length. Thirdly, no writer, as far as we know, has looked at the theories under consideration simultaneously. Examining them alongside each other for the purpose of determining how satisfactorily they accommodate particular aspects of tort law reveals features of the theories - and weaknesses in them - that have not previously been recognised. Fourthly, most of the theories under consideration have usually been put to proof only in just one or two jurisdictions. ${ }^{26}$ This article, uniquely, subjects the theories to scrutiny in all of the major common law jurisdictions.

As we have noted, the universality of our target theories is not a feature of them that previously has been recognised let alone subjected to sustained critique. ${ }^{27}$ It is important to appreciate that investigating the theories as universal theories is a worthwhile enterprise even if Weinrib, Stevens and Posner had confined their theories to just a single jurisdiction. In other words, even if each of these theorists had intended to limit his theory to a single jurisdiction - which it is clear they did not, given the quotes and features of their work that we have just mentioned - it would nonetheless useful to determine whether their theories could be extended to other jurisdictions.

\footnotetext{
26 Id.

27 See the text accompanying supra notes 16-24.
} 
We concentrate on the theories of tort law advanced by Weinrib, ${ }^{28}$ Stevens and Posner. We are conscious of the fact that variations on the ideas propounded by these theorists have been developed by other writers, ${ }^{29}$ and that there are also distinct theories of tort law on offer. However, we focus on the writings of these target theorists partly because of limitations of space but primarily because their theories are in vogue. ${ }^{30}$ They are all deservedly very widely discussed, ${ }^{31}$ and they can fairly be described as leading theories of tort law. We occasionally refer to the writings of other theorists. In particular, we refer periodically to the scholarship of Goldberg and Zipursky. Goldberg and Zipursky have also developed a theory of the entirety of tort law - their "civil recourse theory”. ${ }^{32}$ There are compelling reasons to believe that they,

${ }^{28}$ Weinrib, perhaps to a greater degree than the other theorists with whose work we are concerned, has changed his tune in relation to his model of tort law in certain important respects. This is not surprising given the length of time over which Weinrib has been writing. This observation, we hasten to add, is not meant as any criticism. On the contrary, we read Weinrib has having strived to refine and clarify his important account. However, for the purposes of this article we look mainly to his seminal work, The Idea of Private Law (Weinrib, supra note 1), although we take account in various places of certain of his other writings. We have chosen to proceed in this way for two main reasons. First, The Idea of Private Law is the most sustained defense of his corrective justice model that has he offered by a considerable margin. Secondly, it is important to ascertain whether the analysis that Weinrib advances in The Idea of Private Law is valid despite the fact that Weinrib may have retreated or modified certain of the claims that he made in it. This is because simply because Weinrib has changed his position in relation to certain points not mean that he is correct to have done so.

29 Jules Coleman, for example, has offered several versions of his corrective justice theory of tort law, all of which differ in certain respects from that of Weinrib: see Jules Coleman, Risks and Wrongs §§ 16-18 (1992).

30 Although Posner's scholarship belongs to what is often call the "first wave" of law-and-economics analysis, and although later generations of economic analysis have been predominantly concerned to supply prescriptive rather than explanatory accounts of the law, there is little or nothing of Posner's pioneering work that is now considered by law-and-economics scholars to be obsolete or wrongheaded. Rather, it is generally taken to be foundational, and in this sense retains current appeal. For a detailed account of the various "waves" of North American law-and-economics scholarship, see Neil Duxbury, Patterns of American Jurisprudence 301-419 (1995).

31 Weinrib's work on corrective justice has been the subject of at least one symposium: Formalism, Corrective Justice and Tort Law Symposium: Corrective Justice and Formalism: The Care One Owes One's Neighbors in 77 Iowa L. Rev. i (1992). Stevens's rights theory is the main focus of Rights and Private Law (Donal Nolan \& Andrew Robertson eds., 2012). Some of the articles in which Posner developed his economic theory of tort law (see the sources mentioned in supra note 15) are, of course, some of the most cited law journal articles in the world.

32 Their writings are voluminous. Their main contributions (writing separately or together) include Benjamin C. Zipursky, Rights, Wrongs, and Recourse in the Law Torts, 51 Vand. L. Rev. 1 (1998); John C.P. Goldberg \& Benjamin C. Zipursky, Unrealized Torts, 88 Va. L. Rev. 1625 (2002); Benjamin C. Zipursky, Civil Recourse, Not Corrective Justice, 91 Geo. L. J. 695 (2003); John C.P. Goldberg \& Benjamin C. Zipursky, Tort Law and Moral Luck, 92 Cornell L. Rev. 1123 (2007). A reasonable conspectus of their work to date on civil recourse 
too, intend their theory to be universal in nature. ${ }^{33}$ However, we have not selected them for separate treatment. Their account is in several key respects very similar to Stevens's. ${ }^{34}$ Goldberg and Zipursky condemn attempts to understand tort law as a system for allocating losses caused by accidents and instead "argue... for the descriptive superiority" 35 of a rightsbased (or, as they generally prefer to put it, wrongs-based) view. We have chosen to focus on Stevens rather than on Goldberg and Zipursky primarily because he generally applies his theory to more of the rules in which we are interested in this article than do Goldberg and Zipursky and because Stevens' theory is nakedly universal in its claims. However, what we say about Stevens's theory, we believe, often also holds true for Goldberg and Zipursky's, although we do not seek to establish that this is the case.

At the end of this article, we anticipate and seek to fend off at length a variety of general objections that might be pressed against our analysis. We explain why it would be unconvincing to respond to our analysis by asserting, among other things, that the theories in question are somehow immune to being criticised on the basis that they do not fit the law, that

theory can be found in John C.P. Goldberg \& Benjamin C. Zipursky, Torts as Wrongs, 88 Tex. L. Rev. 917 (2010).

33 Goldberg and Zipursky are much less clear than one would hope on the issue of which system or systems of tort law they are endeavoring to explain. (We are not alone in thinking this: see, e.g., John Gardner, Torts and Other Wrongs, 39 Fla. St. U. L. Rev. 43, 43 (2011).) At a minimum, they are endeavoring to explain tort law in the United States since they cite materials from a wide range of jurisdictions in that country. But they also frequently reference English decisions, and seem to suggest that English tort law and United States tort law are siblings rather than distant cousins by use of the phrase "Anglo-American tort law" (see, e.g., Goldberg and Zipursky, Torts as Wrongs, supra note 32, at 968). When they speak at gatherings of Commonwealth lawyers they do not modify their theory (see, e.g., John C.P. Goldberg \& Benjamin C. Zipursky, Rights and Responsibility in the Law of Torts in Rights and Private Law § 9 (Donal Nolan \& Andrew Robertson eds., 2012), which is based on a lecture that they delivered in England), and the same can be said of articles that they publish in Commonwealth law journals (see, e.g., Benjamin C. Zipursky, Civil Recourse and the Plurality of Wrongs: Why Torts are Different, New Zealand Law Review 145 (2014)). It is reasonable to infer, therefore, that they too consider that their theory holds true throughout the common law world.

34 Some writers also see a strong connection between the work of Goldberg and Zipursky and Weinrib's corrective justice theory. See, e.g., Scott Hershovitz, Corrective Justice for Civil Recourse Theorists, 39 Fla. St. U. L. Rev. 107 (2011); Weinrib, supra 19. Cf. Zipursky, Civil Recourse, Not Corrective Justice, supra note 32. We do not deny that these theories have much in common. However, we see the link between Stevens and Goldberg and Zipursky as being the closer one. And, either way, it is possible to bracket, at least in a rough and ready way, the work of Goldberg and Zipursky with that of other scholars.

35 Goldberg and Zipursky, Torts as Wrongs, supra note 32, at 920 (emphasis added). 
the theories are interpretive theories rather than explanatory and that we have ignored aspects of tort law that the theories can explain. However, a doubt that might be entertained in relation to our enterprise that we want to address squarely at the outset is whether it makes sense to test the theories in question as universal theories. It might be thought that it would be better to ask, first, whether the theories are plausible accounts of tort law in their "home" jurisdictions before testing them against a range of common law jurisdictions. There are two points that we want to make in this connection. The first point is that work of this kind already largely has been done elsewhere. Complaints have often been made that the theories concerned do not fit the law in specific jurisdictions. ${ }^{36}$ We see no point in covering such ground again (although the fact that we highlight problems of fit in a range of jurisdictions means that those earlier studies will receive incidental support from the present article). By contrast, our aim is examine whether the theories in question are plausible universal theories of law - a fundamentally different and novel line of enquiry. The second point is that it is doubtful that the theories really have a "home" jurisdiction. As we have shown, the authors of the theories in question clearly do not confine themselves to individual jurisdictions. This previously unrecognised feature of the theories reveals that it is inadequate merely to test the theories against the law in just one jurisdiction (which is all that existing analyses have done). The theories under consideration are universal theories and it consequently is important that they be tested as such. This work has not been performed to date, and it is this significant gap in tort law scholarship that this article fills.

The bulk of this article is contained in the next part. We test in that section the theories offered by Weinrib, Stevens and Posner against tort law in Australia, Canada the United Kingdom and the United States. Our overall conclusion from this analysis is that the theories in question suffer from significant problems of fit. The scale of the problems is such that we

36 See, e.g., the sources mentioned in supra $\mathrm{n} 25$. 
are unpersuaded that any of them is a satisfactory universal theory. As promised, we conclude the article by anticipating and addressing some general objections that might be levelled against our analysis.

\section{FIVE SIGNIFICANT PROBLEMS OF FIT FOR THE UNIVERSAL THEORIES}

In this part of the article, we discuss problems of fit that the three theories in question encounter when they are applied to the law in Australia, Canada, the United Kingdom and the United States. We assess the theories by reference to five areas of tort law: (1) the breach element of the action in negligence; (2) liability for negligently inflicted pure economic loss; (3) punitive damages; (4) the defense of illegality; and (5) the rule in Rylands v. Fletcher and its descendants.

We have selected these areas primarily because they present significant problems of fit for the theories under consideration qua universal theories. We concentrate on significant problems of fit because we are eager to avoid it from justifiably being suggested that we have selected de minimis problems. (We recognise that, inevitably, there will be at least some mismatch between a theory of a given area of the law and the law in that area.) What do we mean by a "significant” problem of fit? We regard a problem of fit as being "significant” if it is: (1) well out of line with a core tenet of the theory concerned; (2) of practical importance by virtue of the regularity with which it is applied; and (3) found in a multiplicity of jurisdictions. This is, we think, an extremely demanding test for significance. We have deliberately set a particularly high bar (and probably far higher than is necessary ${ }^{37}$ ) so that

\footnotetext{
37 The fact that we have built into our test for significance a wide margin of error means that it is unnecessary for us to pinpoint the degree of mismatch that must exist between a theory and a body of law before a problem of fit properly can be said to exist. See further Part III below.
} 
there is no doubt that the problems of fit that we identify below as significant genuinely are significant.

Needless to say, many other problems of fit additional to those that we have just mentioned also exist, but we confine ourselves to these five problems because they meet our exacting test of significance. We discuss each of the five problems in turn, explaining why they present difficulty for Weinrib’s corrective justice theory, Stevens's rights theory and Posner's economic theory. We do not always consider these theories in the same order as we believe that the best sequence in which to address them depends on the area of law in question.

It is vital to appreciate that the goal of this part of the article is not to highlight differences in the law between the jurisdictions with which we are concerned. Simply drawing attention to such differences would be pointless for current purposes. That is because the theories in question may be able to account for more than one rule that governs a given factual scenario. Proceeding in this way also may result in important problems of fit being overlooked since a rule that a theory cannot explain may be adopted in all of the jurisdictions in issue. The overarching aim of this part of the article is, rather, to explain why rules that are found in the jurisdictions in issue cannot be accommodate by the theorists in question.

\section{A.The Breach Element of the Action in Negligence}

\section{Economic theory}

Different tests are used in different parts of the world to determine when the breach element of the action in negligence is satisfied. According to conventional wisdom, the test that is used in the many jurisdictions in the United States is that propounded in United States $v$. 
Carroll Towing Co. ${ }^{38}$ American law students are usually taught that, in this famous case, Judge Learned Hand laid down an algebraic formula for ascertaining whether the defendant had breached his duty of care. According to this formula, the breach element is determined by reference to the probability of damage to the plaintiff materialising ("P”), the burden of taking precautions ("B”), and the loss that the defendant's conduct caused to the plaintiff ("L”). If PL is greater than B the defendant is adjudged to have breached his duty.

Although the Hand formula has been enshrined in the Restatement (Third) of Torts: Liability for Physical and Emotional Harm ${ }^{39}$ and is accepted as representing the law by many American treatise writers, ${ }^{40}$ we acknowledge that some scholars consider it to have at best a shaky foothold in American tort law. ${ }^{41}$ Carroll Towing is not, actually, even a tort case (it is an admiralty case), and in it Judge Learned Hand was dealing with the plaintiff's fault rather than the defendant's. However, for the purposes of this analysis, we will proceed on the basis that the conventional understanding is correct, namely, that the Hand formula specifies when the breach element will be satisfied in the United States.

The Hand formula is presented by Posner as powerful evidence in support of his theory of tort law. ${ }^{42}$ Indeed, it is probably fair to say that the Hand formula is the main jewel in the crown of that theory. Posner claims that the Hand formula is used not just in the United States but also in the United Kingdom, even if it is not on the lips of the English judges. ${ }^{43}$ He writes:

$38 \quad 159$ F 2d 169, 173 (2nd Cir, 1947).

$39 \S 3$. Wright describes this section as "explicitly adopt[ing] an almost totally unconstrained, reductionist, costbenefit test of reasonableness in negligence law": Richard W. Wright, Justice and Reasonable Care in Negligence Law, 47 American Journal of Jurisprudence 143, 161 (2002).

40 See, e.g., Prosser and Keeton on Torts 173 (David Owen, et al. eds., 5th ed. 1984); Dan Dobbs, The Law of Torts 340-348 (2000).

41 See, e.g., Richard W. Wright, Hand, Posner, and the Myth of the "Hand Formula", 4 Theoretical Inquiries in Law 1 (2003); Benjamin C. Zipursky, Sleight of Hand, 48 Wm. \& Mary L. Rev. 1999 (2007).

42 See, e.g., Landes and Posner, supra note 14, at 85-88.

43 Posner's claim that the formula is rarely mentioned by English judges is correct. Indeed, it is mentioned only exceptionally in Commonwealth jurisdictions more generally. We searched high and low for references to the Hand Formula by Commonwealth judges. We were able to unearth only a handful of occasions on which it was mentioned. Instances when it was referred to include Western Suburbs Hospital v. Currie, (1987) 9 
"I do not know how many English judges have heard of the Hand formula. But I think that if it were explained to them they would accept it as a fair description of the modern English law of negligence". ${ }^{44}$ The relevant problem for Posner is that the Hand formula is simply not used outside of the United States. It has been stressed by the courts in several jurisdictions that the breach element is not determined in a mathematical way or by a calculus. ${ }^{45}$ Furthermore, factors other than those referred to in the formula are often considered. As McHugh JA said in the decision of the New South Wales Court of Appeal in Western Suburbs Hospital v. Currie: "Negligence is not an economic cost/benefit equation. Immeasurable "soft" values such as community concepts of justice, health, life and freedom of conduct have to be taken into account”. ${ }^{46}$ Equivalent statements have been made in other jurisdictions. ${ }^{47}$ Textbook writers in Commonwealth countries, while they often refer to the Hand formula in passing, do not suggest that it constitutes the law in the jurisdiction with which they are concerned. ${ }^{48}$ For

NSWLR 511, 523-524 (C.A.); Rentway Canada Ltd/Ltée v. Laidlaw Transport Ltd, (1989) 49 CCLT 150, para 46 (H.C.J.); Cekan v. Haines, (1990) 21 NSWLR 296, 306 (C.A.); Ultramar Canada Inc v. “Czantoria”, (1994) 84 FTR 241, para 125 (Aust. Fed. Ct.); Opron Construction Co v. Alberta, (1994) 151 AR 241, para 702 (Alta. Q.B.); Dovuro Pty Ltd v. Wilkins, [2000] FCA 1902, (2000) 182 ALR 481, para 96; Re Commins and Civil Aviation Safety Authority, [2004] AATA 1330, (2004) 86 ALD 637, para 23; Twin Cities Mechanical \& Electrical Inc v. Progress Homes Inc, (2005) NLTD 134, (2005) Nfld \& PEIR 314, para 41; Gemoto v. Calgary Regional Health Authority, [2006] ABQB 740, (2007) 2 WWR 243, para 21; Blackstrap Hospitality Corp v. Aztec Amusements, (1992) Ltd, [2009] ABQB 74, para 88.

44 Posner, supra note 21, at 41 (footnote omitted).

45 'Reference to 'calculus', 'a certain way of performing mathematical investigations and resolutions', may wrongly be understood as requiring no more than a comparison between what it would have cost to avoid the particular injury that happened and the consequences of that injury": New South Wales v. Fahy, [2007] HCA 20, (2007) 81 ALJR 1021, para 57 (footnote omitted); "What is involved ... is not a calculation; it is a judgment”: Mulligan v. Coffs Harbour City Council, [2005] HCA 63, (2005) 223 CLR 486, para 2.

46 (1987) 9 NSWLR 511, 523 (C.A.). The High Court of Australia has made similar remarks on several occasions: see, e.g., New South Wales v. Fahy, [2007] HCA 20, (2007) 81 ALJR 1021, paras 6, 125 (stressing that the breach element of the tort of negligence is not resolved by way of a "calculus" and cannot be determined in a scientific or mathematical way).

47 E.g., in Ridge v. Baldwin, [1964] AC 40, 65 (H.L.) Lord Reid remarked that "[t]he idea of negligence is ... insusceptible of exact definition”.

48 E.g., John Fleming, speaking principally about Australian law, noted that "the reasonable person is by no means a caricature cold blooded, calculating Economic Man”: John G. Fleming, Fleming's the Law of Torts para 7.130 (Carolyn Sappideen \& Prue Vines ed. 10th ed. 2011). This passage is materially identical to the corresponding one in the last edition of this book that Fleming himself authored: John G. Fleming, The Law of Torts 132 (9th ed. 1998). 
these reasons, Posner's account suffers from significant difficulty when applied outside the United States.

It might be thought that this conclusion has been reached too hastily since Posner has never actually claimed that the Hand formula is employed anywhere with mathematical precision. It might also be argued that the Hand formula is broad enough, in principle, to allow for all costs and benefits to be weighed, and not merely those that are economic in nature. On this basis, the Hand formula could be seen as capable of accommodating the "soft" values referred to by McHugh JA. Such values are, it might be said, simply certain nominate factors that are relevant to a cost-benefit analysis. Despite some ostensible appeal, this line of argument ultimately is unpersuasive. To begin with, the various "soft" values of liberty, justice and life, are not easily cashed out in economic terms. This is important because judicial consideration of factors that are not reducible to economic values is flatly inconsistent with Posner's purely economic theory of tort law. Furthermore, we doubt whether Commonwealth courts simply balance all costs and benefits for the simple reason that "life, liberty and justice" are incommensurable values. They cannot be compared according to any common metric. This, too, is highly significant since Posner's economic model is predicated on relevant considerations being susceptible to being weighed.

\section{Corrective justice}

For the other theorists with whom we are concerned, the converse problem exists. That is, they are unable to explain the fact that the Hand Formula is used in the United States. This is properly conceded by Weinrib. He admits that his theory cannot accommodate the Hand formula because that formula takes cognizance of the burden on the defendant of taking 
precautions. ${ }^{49}$ Pursuant to his theory, a factor that is relevant to liability must be bilateral in the sense that it is concerned with the relationship between the parties. ${ }^{50}$ However, the cost to the defendant of taking precautions is not something that connects the parties to each other. It is a unilateral consideration that is concerned solely with the defendant. Whereas Weinrib admits, therefore, that his corrective justice theory does not accommodate the law regarding the breach element of the action in negligence in the United States (surely a major concession), he claims that his theory fares much better when attention is turned to other jurisdictions. He says that "the English and Commonwealth approach to reasonable care ignores [the burden on the defendant of avoiding the risk] almost completely”. ${ }^{51}$ Weinrib is badly mistaken here about the state of the law (a fact that seems to have passed wholly unnoticed by other scholars). Although it is true that the cost to the defendant is not always as explicitly and directly factored into the determination of the breach issue by Commonwealth courts as it is by the Hand formula, the suggestion that the cost to the defendant of taking precautions is irrelevant or nearly irrelevant is manifestly false. Weinrib’s analysis of the law on this point ${ }^{52}$ relies heavily on the landmark Australian case of Wyong Shire Council v. Shirt. ${ }^{53}$ There, in one of the most celebrated opinions in Australian tort law, Mason J said that the cost of taking precautions is a factor to consider in determining whether the defendant breached his duty. His Honor wrote: “The perception of the reasonable man’s response calls for a consideration of the magnitude of the risk and the degree of the probability of its occurrence, along with the expense, difficulty and inconvenience of taking alleviating action

\footnotetext{
49 Weinrib, supra note 1 , at 148 .

50 Id. at $120-121$.

51 Id. at 148.

52 Id. at $148 \mathrm{n} 2$.

53 (1980) 146 CLR 40 (Aust. H.C.).
} 
and any other conflicting responsibilities which the defendant may have". ${ }^{4}$ Shirt, therefore, far from supporting Weinrib’s theory, actually undermines it.

Weinrib also cites the famous English case of Bolton v. Stone ${ }^{55}$ in support of his claim that in Commonwealth jurisdictions the burden on the defendant of avoiding the risk in question is "ignor[ed] ... almost completely" ${ }^{56}$ In this case the plaintiff was injured when she was struck by a cricket ball that had been hit out of the grounds. It is true that Lord Reid's opinion contains some remarks that are in tune with Weinrib’s position. For example, his Lordship said, "I do not think that it would be right to take into account the difficulty of remedial measures. If cricket cannot be played on a ground without creating a substantial risk, then it should not be played at all”. ${ }^{57}$ However, it is very doubtful whether Lord Reid really meant to say that the practicability of taking precautions is irrelevant, given that in two subsequent cases he indicated that the cost of precautions should be taken into account. ${ }^{58}$ Furthermore, even if he did hold that view when he delivered his speech in Bolton v. Stone, it is doubtful whether that section of his speech forms part of the ratio decidendi of the case. The Appellate Committee that heard the appeal in Bolton v. Stone comprised five law lords. The Committee unanimously upheld the finding of the trial judge that there was no breach of duty, and all five law lords delivered speeches. Only Lord Reid can be read as suggesting that the cost of taking precautions could be disregarded in that case, a fact that Weinrib omits to mention.

54 (1980) 146 CLR 40, 47-48 (Aust. H.C.) (emphasis added). This passage has essentially been put on a statutory footing in many Australian jurisdictions: see, e.g., Civil Liability Act (NSW) § 5B (2002).

55 [1951] AC 850 (H.L.).

56 Weinrib, supra note 1 , at 148.

57 [1951] AC 850, 867 (H.L.) 867.

58 In Morris v. West Hartlepool Steam Navigation Co, [1956] AC 552, 574 (H.L.) 574 Lord Reid said that "the difficulty and expense and any other disadvantage of taking the precaution” must be weighed in deciding whether there is a breach of duty. Also, in the Wagon Mound (No 2), [1967] 1 AC 617, 642 (P.C. (Aust.)) 642, he opined that "a reasonable man would only neglect ... a risk [of very small magnitude] if he had some valid reason for doing so, e.g., that it would involve considerable expense to eliminate the risk". 
Many English judges, ${ }^{59}$ and judges elsewhere in the Commonwealth, ${ }^{60}$ have said that the cost of taking precautions is relevant (though by no means central) to the issue of breach of duty. It is thus unsurprising that commentators have noted that the cost to the defendant of taking precautions is a salient factor in determining whether the breach element of negligence is satisfied. John Fleming, for example, summarising the gist of the authorities, wrote: "That the cost [to the defendant of avoiding the risk of injury] ... is a relevant factor cannot be doubted". ${ }^{61}$ Because the cost of implementing risk-prevention measures is a factor to consider in deciding whether there has been a breach in all Commonwealth jurisdictions as well as in the United States, Weinrib’s theory suffers from a significant problem of fit. It does not admit of universal application.

\section{Rights theory}

Stevens rightly acknowledges that his theory faces a significant problem whenever cost to the defendant is taken into account by tort law. ${ }^{62}$ The problem arises because this consideration has nothing to do with the plaintiff's rights. ${ }^{63}$ Since cost to the defendant is relevant to determining whether there is a breach of duty (a fact which Stevens notes ${ }^{64}$ ) in all of the jurisdictions with which we are concerned, Stevens's theory suffers from a major problem of fit. In an attempt to mitigate this difficulty, Stevens seeks to discredit Posner's economic

59 See, especially, Latimer v. AEC Ltd, [1953] AC 643, 653 659, 662-663 (H.L.).

60 See, e.g., Botting v. British Columbia, (1996) 27 BCLR (3d) 106, para 30.

61 John Fleming, The Economic Factor in Negligence, 108 LQR 9, 9 (1992).

62 Stevens, supra note 9, at 92-93.

63 One might argue that our rights depend at least in part on how burdensome certain conduct required by those rights would be for others. This is not, however, how Stevens perceives the rights protected by tort law. In his view, the rights protected by the common law "are inevitably derived from moral rights" (id. at 331). He also remarks: "[m]oral rights are capable of justification independently of their utility or consequences... Utilitarian or consequentialist arguments for their recognition ... are otiose” (id. at 333).

64 Id. ("it is observably true that in a claim based upon the defendant's negligence, the courts take into account the costs and benefits of a defendant's actions in determining whether he is liable”) (footnote omitted). 
account of tort law, ${ }^{65}$ which champions consideration of cost to the defendant. However, this attempt to rescue his theory rests on a logical error. ${ }^{66}$ This is because even if Stevens's criticisms of Posner's theory are convincing, that would not support Stevens's own theory. The fact that one theory is inadequate does not thereby make a rival theory acceptable. Stevens's move, repeatedly made throughout his Torts and Rights, ${ }^{67}$ is akin to stating that the heliocentric theory of the universe (the theory that the sun is at the centre of the universe) provides the best explanation of the position of objects in the universe simply because the geocentric theory (the theory that Earth is at the centre of the universe) is flawed. It is a classic example of what philosophers call the fallacy of the excluded middle. The difficulty from which Stevens's account suffers in relation to the breach element in negligence actions therefore remains and it means that his theory cannot claim universal truth.

\section{B. Negligently Inflicted Pure Economic Loss}

\section{The law}

All of the jurisdictions with which we are concerned adopt different approaches to the recognition of a duty of care in respect of negligently inflicted pure economic loss. In Australia, the question in each case is whether the "salient features" of the proceedings call for a duty to be recognized. ${ }^{68}$ Salient features include the plaintiff's vulnerability, ${ }^{69}$ the risk of

65 Id. at 93-97. Stevens's assault on Posner's theory comes from many directions. We do not address whether the assault succeeds because, as we explain, that fact is irrelevant to the success or failure of Stevens's own theory.

66 This point is Peter Cane’s: Peter Cane, Torts and Rights, 71 MLR 641, 643 (2008).

67 Numerous illustrations are given by Cane: $i d$.

68 Perre v. Apand Pty Ltd, [1999] HCA 36, (1999) 198 CLR 180; Woolcock Street Investments Pty Ltd v. CDG Pty Ltd, [2004] HCA 16, (2004) 216 CLR 515.

69 See, e.g., Graham Barclay Oysters Pty Ltd v. Ryan, [2002] HCA 54, (2002) 211 CLR 540, paras 84, 149, 321. 
imposing indeterminate liability, ${ }^{70}$ the control enjoyed by the defendant over the circumstances that led to the plaintiff suffering injury, ${ }^{71}$ the defendant's knowledge ${ }^{72}$ and the need to protect individual autonomy. ${ }^{73}$ In Canada, the Anns test is used to determine when a duty of care arises, ${ }^{74}$ including in cases involving negligently inflicted pure economic loss. ${ }^{75}$ According to the Anns test, the issue of whether a duty of care is owed is resolved in two stages. The first stage involves enquiring whether there is sufficient "proximity” between the parties. If the necessary proximity exists, the second stage becomes relevant, where it is asked whether there are any policy considerations which limit or exclude a duty.

The position in the United Kingdom contrasts starkly with that in Australia and Canada. In the United Kingdom, a distinction is drawn between two types of case: (1) those involving an assumed responsibility; and (2) those involving what is often referred to as "relational economic loss”, (that is, pure economic loss caused to the plaintiff by virtue of the knock-on effect of the defendant having negligently harmed the property or person of a third party). A bright-line rule excludes the imposition of a duty in the second kind of case. ${ }^{76}$ A duty may, however, arise in the first type of case $^{77}$ pursuant to the Caparo test ${ }^{78}$ or a test that asks whether the defendant assumed responsibility for the plaintiff. ${ }^{79}$ In the United States, a duty

70 See, e.g., Perre v. Apand Pty Ltd, [1999] HCA 36, (1999) 198 CLR 180, paras 32, 50, 106-113, 298-299, 335-340, 395.

71 See, e.g., Burnie Port Authority v. General Jones Pty Ltd, (1994) 179 CLR 520, 551-552 (Aust. H.C.).

72 See, e.g., Crimmins v. Stevedoring Industry Finance Committee, [1999] HCA 59, (1999) 200 CLR 1, paras 43, 46, 101-102, 233 (1999).

73 See, e.g., Perre v. Apand Pty Ltd, [1999] HCA 36, (1999) 198 CLR 180, paras 114-117, 133, $300,335$.

74 Originally developed in Anns v. Merton LBC, [1978] AC 728 (H.L.).

75 Nielson v. Kamloops (City), [1984] 2 SCR 2 (S.C.C.); Hercules Managements Ltd v. Ernst \& Young, [1997] 2 SCR 165 (S.C.C.); Canadian National Railway Co v. Norsk Pacific Steamship Co, [1992] 1 SCR 1021 (SCC).

76 Leigh and Sillivan Ltd v. Aliakmon Shipping Co Ltd, [1986] AC 785 (H.L.).

77 See, e.g., Hedley Byrne \& Co v. Heller \& Partners Ltd, [1964] AC 465 (H.L.); Henderson v. Merrett Syndicates Ltd, [1995] 2 AC 145 (H.L.); White v. Jones, [1995] 2 AC 207 (H.L.).

78 Caparo Industries plc v. Dickman, [1990] 2 AC 605 (H.L.); Customs and Excise Commissioners v. Barclays Bank plc, [2006] UKHL 28, [2007] 1 AC 181, paras 53, 82-83.

79 Hedley Byrne \& Co v. Heller \& Partners Ltd, [1964] AC 465 (H.L.); Henderson v. Merrett Syndicates Ltd, [1995] 2 AC 145 (H.L.). 
of care will generally be recognized in respect of pure economic loss in assumption of responsibility cases. ${ }^{80}$ The position is complicated, however, as regards relational economic loss cases because of a diversity of views taken in different states. That said, most states adopt a robust exclusionary rule, which is often referred to in the United States as the "economic loss doctrine” ${ }^{81}$ That rule is endorsed by $\S 766 C$ of the Restatement (Second) of Torts. ${ }^{82}$ This section states: "One is not liable to another for pecuniary harm not deriving from physical harm to the other”. Broadly speaking, therefore, the relevant law in the United States is similar to that in the United Kingdom.

\section{Rights theory}

Stevens starts his discussion of relational economic loss from the premise that the common law recognizes no general right to economic well-being. ${ }^{83}$ Given his belief that tort law is about the infringement of rights, he goes on to assert that, "[since] the infliction of economic loss does not per se infringe any right of the plaintiff ... [it] is not therefore prima facie recoverable”, ${ }^{84}$ In making such claims, Stevens encounters significant difficulty in relation to the law in both Australia and Canada for in both of those jurisdictions such losses may sometimes be recovered. In Australia, as noted above, one may recover damages in respect of negligently inflicted pure economic loss according to the salient features test, while in Canada, such losses may sometimes be recovered under the Anns test. Stevens rightly admits

\footnotetext{
80 Restatement (Second) of Torts $\S 522(1)$.

81 For a recent overview of the position in the United States, see Ronen Perry, Economic Loss, Punitive Damages, and the Exxon Valdez Litigation, 45 Ga. L. Rev. 409 (2011).

82 See also Restatement (Third) of Torts: Liability for Economic Harm (Tentative Draft No 2) § 7.

83 Regarding this premise, see Kit Barker, Relational Economic Loss and Indeterminacy: The Search for Rational Limits in Torts in Commercial Law 171-172 (Simone Degeling, James Edelman \& James Goudkamp eds., 2011).

84 Stevens, supra note 9, at 21.
} 
this clash with his theory. ${ }^{85}$ In an attempt to overcome the problem, Stevens criticizes the law in Australia and Canada. So, whereas he asserts the superiority of the English approach (according to which damages for relational economic loss is irrecoverable on grounds that chime with his rights theory), he denounces the leading Australian cases on relational economic loss of Caltex Oil (Australia) Pty v. The Dredge "Willemstad" 86 and Perre v. Apand Pty $L t d^{87}$ on the basis that they comprise instances of judicial "radicalism”. This "radicalism", he believes, inheres in the fact that the courts permitted recovery in them without “articulat[ing] any right [that was] violated". ${ }^{88}$ In relation to Canadian law, Stevens's criticism can only be inferred. While he does not discuss directly the relevant Canadian cases, he maintains that "the greatest 20th century judicial disaster in the law of torts was the decision of the House of Lords in Anns v. Merton London Borough Council". ${ }^{89}$ And, of course, as noted earlier, it is the Anns test that is still used in Canada (thereby providing the means by which claims for negligently inflicted pure economic loss may succeed in that country). Thus, in relation to both Australia and Canada, Stevens's message is clear: the courts in both of these jurisdictions have erred in their treatment of relational economic loss. The inference is that he thinks that the law in both countries ought to be changed. Stevens's analysis, however, does nothing to rescue his theory. This is because his argument is a prescriptive one. Such arguments do nothing to keep the promise made by Stevens to provide an explanation of the law as it exists. ${ }^{90}$ If someone sets themselves up as the purveyor of an explanatory theory, as Stevens does, then their self-imposed task is to account for the law as we find it. In saying this we do not, of course, mean to suggest that scholars should not

\footnotetext{
85 Stevens, supra note 17 , at 45-49.

86 (1976) 136 CLR 529 (Aust. H.C.).

87 (1999) 198 CLR 180 (Aust. H.C.).

88 Stevens, supra note 17 , at 49.

89 Id. at 53.

90 See the text accompanying supra notes 9-12.
} 
engage in prescriptive analysis of tort law. Our point is simply that it is impossible to show that a given rule fits a purportedly explanatory theory by contending that the rule should be altered so that it conforms to the theory.

Stevens's treatment of assumed responsibility cases is also suspect. In his view, the assumption of responsibility cases in which damages in respect of pure economic loss have been recovered are unproblematic because in such cases a right to economic welfare does exist. According to Stevens, the defendant's objective manifestation of willingness to undertake a responsibility towards the plaintiff is a right-generating act by analogy with the rights created by gratuitous bailment and by virtue of estoppels and express trusts. ${ }^{91}$ In all such cases, according to Stevens, the fact that the defendant has voluntarily assumed a responsibility towards the plaintiff confers upon the plaintiff a right that the plaintiff would not otherwise have. On this basis, the assumed responsibility cases in tort are consistent with Stevens's theory: the plaintiff possesses a right the infringement of which enables him to sue the defendant. A problem with this explanation is that Stevens offers no reason as to why the law in relation to bailment, estoppel or express trusts should be thought to provide a better guide as to the way in which tort law should be understood as handling voluntary assumptions of responsibility than, for example, the law of contract where, of course, gratuitous undertakings are not prima facie binding, and hence do not invest the promisee with a right that he would not otherwise possess. Stevens's explanation is simply question-begging.

\section{Corrective justice}

The idea that torts are infringements of rights also plays an important role in Weinrib's corrective justice theory, although it does not have quite the same prominence in his theory as

\footnotetext{
91 Stevens, supra note 9 , at $10-11$ and 33.
} 
it does in Stevens’s (where rights occupy centre stage). Weinrib writes: “A right immediately signifies the existence of a correlative duty; harm or loss does not. Neither the harm as something suffered by the plaintiff nor the process of suffering it at the defendant's hand establishes a link between the parties that is at once correlative and juridically normative", ${ }^{92}$ The fact that Weinrib embraces these propositions exposes his theory to essentially the same difficulty as that which afflicts Stevens's when it comes to the law governing negligently inflicted pure economic loss. Frequently, courts across the common law world take into account factors beyond whether the defendant has infringed the plaintiff's rights (if they take that consideration into account at all) in deciding whether to impose a duty of care in respect of pure economic loss. The focus is often on the fact that the plaintiff has suffered pure economic loss and on how to delimit the circumstances in which damages for such loss can be recovered. A regularly discussed consideration in this connection, and perhaps the most noteworthy for present purposes, is the prospect that recognizing a duty of care will impose indeterminate liability on the defendant. ${ }^{93}$ This is widely acknowledged as a reason for excluding a duty of care in respect of pure economic loss in circumstances where a duty may otherwise arise. This is highly problematic for Weinrib because judicial anxiety about exposing the defendant to indeterminate liability has nothing to do with the rights of the plaintiff. It is a unilateral consideration that concerns only the defendant. The fact that the spectre of indeterminate liability is a reason for excluding a duty that may otherwise exist in all of the jurisdictions with which we are concerned cannot be explained by Weinrib’s theory. This is properly conceded by Weinrib. ${ }^{94}$

92 Ernest J. Weinrib, Corrective Justice 51 (2012).

93 See, e.g., Canadian National Railway Co v. Norsk Pacific Steamship Co, [1992] 1 SCR 1021, 1137, 1153, 1160, 1173, 1176-1183 (S.C.C.); Perre v. Apand Pty Ltd, [1999] HCA 36, (1999) 198 CLR 180, paras 32, 50, 106-113, 298-299, 335-340, 395; Customs and Excise Commissioners v. Barclays Bank plc, [2006] UKHL 28, [2007] 1 AC 181, paras 74, 100 (2007).

94 Weinrib, supra note 92, at 56-57. Weinrib does not seek to mitigate the difficulty that the law presents for his theory. He simply describes the law governing the recovery of damages for negligently inflicted pure 


\section{Economic theory}

Posner contends that efficiency demands the denial of recovery in cases of negligently inflicted pure economic loss. In his view, such cases involve only private costs and no social costs. (On Posner's definition, “a social cost is a diminution in the total value of society’s economic goods; a private cost is a loss to one person that produces an equal gain to another" ${ }^{95}$ ) Because only social costs matter from his economic perspective - where there is no diminution in aggregate social wealth there is no behavior that needs to be deterred ${ }^{96}$ claims in respect of negligently inflicted pure economic loss should be rejected. While this point about private costs and social costs is Posner's main reason for taking this position, he also marshals several subsidiary arguments. Specifically, he contends that plaintiffs in pure economic loss cases are better able than defendants to quantify their loss ex ante ${ }^{97}$ and that the risk of indeterminate liability presented by such cases is a serious impediment to the prospect of efficient precaution-taking by defendants. ${ }^{98}$ We will assume that Posner is correct to say efficiency requires the law to let losses lie where they fall in pure economic loss cases. Yet if this is what efficiency demands, Posner's theory encounters substantial problems.

economic loss as having suffered from a "jurisprudential decline” (at 57). Even if this claim is correct, it does not insulate his theory from the difficulty presented by the law.

95 Richard A. Posner, Common-Law Economic Torts: An Economic and Legal Analysis, 48 Ariz. L. Rev. 737 (2006). Much the same analysis is embraced in William Bishop, Economic Loss in Tort, 2 OJLS 1, 4 (1982).

96 Posner makes this argument by way of a hypothetical example in which access to A's shop is negligently obstructed by B, and A's loss of profits are matched by an equal gain enjoyed by rival store owners. There is no social cost because no goods are lost (they remain unharmed in A's store) and prices do not rise because of a shortage since because "most retail establishments operate most of the time with a bit of excess capacity in order to handle peak demands”: Posner, supra note 95, at 736-737.

97 "[E]fficiency may be promoted by shifting the legal responsibility for an accident from the injurer to the victim": since the latter knows clearly what he stands to lose, he is necessarily "in a better position to avoid the loss by taking appropriate precautions or by buying insurance”: id. at 739. By contrast, a defendant would face huge problems associated with the ex-ante quantification of losses which would serve to "prevent [the defendant] ... from determining how much it should invest in precautions" and make it "difficult, and indeed probably impossible ... to buy insurance against liability”: id. at 737.

98 Id. at 739 . 
In all of the jurisdictions with which we are concerned, tort law permits damages to be recovered in pure economic loss cases involving an assumption of responsibility in certain circumstances. Posner admits the difficulty that this poses for his theory in the course of discussing the decision of the House of Lords in White v. Jones. ${ }^{99}$ In this case, a testator instructed his solicitor to amend his will to include his two daughters as beneficiaries of his estate. The solicitor carelessly failed to follow these instructions with the result that the daughters inherited nothing. Property that the father intended them to receive instead devolved to other individuals. The daughters successfully sued the solicitor in negligence. Because the daughters' loss was a gain to the beneficiaries of the estate, it was a merely private loss. Accordingly, says Posner, in such a case, "it is best for the judges to let the loss lie where it has fallen”. ${ }^{100}$ But this is not what happened. Like claims have succeeded in all of the other jurisdictions with which we are concerned. ${ }^{101}$ And, of course, the difficulty for Posner is not confined to disappointed beneficiary cases, but extends to all assumption of responsibility cases.

What is the situation with respect to relational economic loss cases? As we have noted, in the United Kingdom and the United States a strong exclusionary rule prevents damages from being recovered in such cases. This rule is consistent with Posner's analysis. However, the law is very different in Australia and Canada. We observed earlier that in those jurisdictions

99 [1995] 2 AC 207 (H.L.). It might be doubted whether this case is properly understood as an assumption of responsibility case (consider, e.g., Peter Benson, Should White v. Jones Represent Canadian Law: A Return to First Principles in Emerging Issues in Tort Law 141, 167 (Jason W. Neyers et al. eds., 2007); Nicholas J. McBride \& Roderick Bagshaw, Tort Law 191 (4th ed. 2012).). However, scholars frequently treat it in this way (see, e.g., A. Beever, supra note 18, 303; Kit Barker, Wielding Occam's Razor: Pruning Strategies for Economic Loss, 26 OJLS 289, 290 (2006)), and this is how three of the majority judges in White regarded it: [1995] 2 AC 207, 268, 274, 293-294 (H.L.) per Lord Goff, Lord Browne-Wilkinson and Lord Nolan respectively. We proceed on the basis of this understanding.

100 Posner, supra note 21, at 47.

101 See, e.g., Hill v. Van Erp, (1997) 188 CLR 159 (Aust. H.C.); Earl v. Wilhelm, [2000] SKCA 1, (2000) 189 Sask R 71; Graham v. Bonnycastle, [2004] ABCA 270, (2004) 354 AR 266; Biakanja v. Irving, 49 Cal 2d 647, 320 P 2d 16 (1958). 
relational economic loss claims are sometimes permitted. This result is, by Posner's reckoning, inefficient. The clash with his theory is considerable.

\section{Punitive Damages}

\section{The law}

The availability of punitive damages varies considerably throughout the common law world. In some Australian jurisdictions, the circumstances in which they may be awarded have been severely confined by legislation. This legislation either abolishes them entirely ${ }^{102}$ or eliminates them in certain contexts, such as in claims in respect of personal injuries caused by negligence. ${ }^{103}$ In other parts of Australia, the availability of punitive damages is determined by the common law. At common law, punitive damages are awarded in order "to punish the defendant for conduct showing a conscious and contumelious disregard for the plaintiff's rights and to deter him from committing like conduct again”. ${ }^{104}$ The law governing punitive damages in Canada is broadly similar to the Australian common law. The rule in Canada is that punitive damages "may be awarded in situations where the defendant's misconduct is so malicious, oppressive and high-handed that it offends the court's sense of decency". ${ }^{105}$ The test for the award of punitive damages in the United Kingdom is much more stringent than in both Australia and Canada. The House of Lords in Rookes v. Barnard ${ }^{106}$ famously confined punitive damages to just three types of case. These are (1) cases involving oppressive, arbitrary or unconstitutional conduct on the defendant's part; (2) cases in which the defendant

\footnotetext{
102 See, e.g., Personal Injuries (Liabilities and Damages) Act (NT) § 19 (2003).

103 See, e.g., Civil Liability Act (NSW) § 21 (2002); Civil Liability Act (Qld) § 52 (2003).

${ }^{104}$ XL Petroleum (NSW) Pty Ltd v. Caltex Oil (Australia) Pty Ltd, (1985) 155 CLR 448, 471 (Aust. H.C.).

${ }^{105}$ Hill v. Church of Scientology of Toronto, [1995] 2 SCR 1130, 196 (S.C.C.).

106 [1964] AC 1129 (H.L.).
} 
acted with the intention of making a profit; and (3) cases in which an award of punitive damages is authorised by statute. In the United States, most jurisdictions permit punitive damages to be awarded, typically where the defendant's conduct "constitutes an extreme departure from lawful conduct”. ${ }^{107}$ In many States, legislative caps on the quantum of punitive damages have been enacted and provision has been made for a proportion of any punitive damages awarded to be redirected to a government agency. In a few states, punitive damages can be awarded only when legislation authorises their award. ${ }^{108}$ The general picture that emerges from this mêlée is that punitive damages are available in all of the jurisdictions with which we are concerned, but that their availability differs considerably from one part of the world to another.

\section{Corrective justice}

The situation in relation to punitive damages poses an insurmountable challenge for Weinrib’s theory. Corrective justice, Weinrib tells us, involves placing "the defendant under the obligation to restore the plaintiff, so far as possible, to the position the plaintiff would have been in had the wrong not been committed”. ${ }^{109}$ It follows that punitive damages, which are not reparative in nature, do not effect corrective justice. This is rightly conceded by Weinrib. He writes: "under corrective justice damages are compensatory, not punitive". 110 The challenge that punitive damages present to Weinrib's theory is more acute in some parts of the world than in others. The problem is probably most pronounced in the case of the United States, where punitive damages are generally awarded more freely than anywhere else.

\footnotetext{
107 David G. Owen, The Moral Foundations of Punitive Damages, 40 Ala. L. Rev. 705, 730 (1989).

108 For the details, see Dobbs, supra note 40, at 1074-1075.

109 Weinrib, supra note 1 , at 135 (footnote omitted).

${ }^{110}$ Id. at 135 n 25.
} 
Weinrib attempts to mitigate the problem from which his theory suffers in this regard by suggesting that, in at least some situations, punitive damages are properly understood as restitutionary damages. He points out that, under the second category identified in Rookes $v$. Barnard, punitive damages can be awarded where the defendant has sought to make a gain. In Weinrib’s words: “In Cassell \& Co. v. Broome, [1972] App. Cas. 1027 (H.L.), Lord Diplock explained this second category in terms of unjust enrichment. This explanation would make this category, at least, consistent with corrective justice’s treatment of illegitimate gains”.111 Two things need to be noted here. First, this analysis does nothing to explain away the first and third categories identified in Rookes $v$. Barnard, or the fact that punitive damages are available in other jurisdictions in cases that fall outside of the second category in that case. ${ }^{112}$ Secondly, and more fundamentally, it is abundantly clear that punitive damages are not restitutionary. ${ }^{113}$ Punitive damages may be awarded under the second category in Rookes $v$. Barnard even if the defendant has not in fact made any gain (a mere intention to make a gain can be sufficient to bring a case within that category). ${ }^{114}$ The test, as laid down by Lord Devlin in Rookes $v$. Barnard, is whether the defendant "with a cynical disregard for a plaintiff's rights has calculated that the money to be made out of his wrongdoing will probably exceed the damages at risk". ${ }^{115}$ The crucial issue according to Lord Devlin’s formula is the defendant's motivation, not the result. ${ }^{116}$ Furthermore, even where a defendant

111 Id. Lord Diplock wrote that the second category in Rookes v. Barnard is "analogous to the civil law concept of enrichessement indue": [1972] AC 1027, 1129 (H.L.).

112 Rookes v. Barnard was expressly rejected in Australia in Australian Consolidated Press Ltd v. Uren, [1969] 1 AC 590 (P.C. (Aust.)), affirming (1967) 117 CLR 221 (Aust. H.C.) and Canada in Vorvis v. Insurance Corp of British Columbia, [1989] 1 SCR 1085 (S.C.C.).

113 Even if they were, it is arguable that restitutionary damages are inconsistent with corrective justice. Consider Prince Saprai, Restitution Without Corrective Justice, 14 Restitution L. Rev. 41 (2006). We remain silent on this issue for present purposes.

114 "I do not think that the argument that the defendant could not make a profit here defeats the plaintiff's claim”: Archer v. Brown, 1 QB 405, 423 (Q.B.D.) per Peter Pain J.

115 [1964] AC 1129, 1227 (H.L.).

${ }^{116}$ For an illustration of a case in which the defendant had a profit motive but made no profit yet was nonetheless required to pay punitive damages, see Drane v. Evangelou, [1978] 1 WLR 455 (Ch. D.). 
has made a gain as a result of his tort, the award of punitive damages is calibrated according to the need to punish the defendant rather than the size of the gain made, which is what would be necessary in order for Weinrib’s attempt to accommodate the second category in Rookes $v$. Barnard within his theory to be viable. Hence, at least since Broome v. Cassell \& Co Ltd, ${ }^{117}$ it has been clear that punitive damages awarded under the second category in Rookes v. Barnard will often need to exceed the defendant's gain so that the purpose of awarding damages in category two cases, namely, "to teach a wrongdoer that tort does not pay", ${ }^{118}$ will be achieved. Andrew Burrows notes that this "crucial additional point [shows] that damages under [the] second category are not concerned merely to reverse the defendant's unjust enrichment.” 119 For these reasons, Weinrib’s restitutionary analysis fails to explain away, even in part, the significant problem of fit that punitive damages present for this theory.

Weinrib also seeks to insulate his theory from the existence of punitive damages on the twin grounds that such damages are awarded only exceptionally, and that their very existence is contentious. ${ }^{120}$ He writes that punitive damages are "encased in controversy"121 and claims, further, that the House of Lords in Rookes v. Barnard "unequivocally repudiate[ed]" them as “anomalous" and "restricted their scope to the minimum allowed by precedent". ${ }^{122}$ Weinrib also notes that punitive damages are unavailable in civil law jurisdictions. ${ }^{123}$ The apparent intention of this discussion is to paint punitive damages as a de minimis problem for his theory. We do not dispute the accuracy of any of the observations that Weinrib makes in this connection. However, we doubt whether they deal convincingly with the problem that punitive damages pose for his theory. It is true that awards of punitive damages are relatively

\footnotetext{
117 [1972] AC 1027 (H.L.).

${ }^{118}$ [1972] AC 1027, 1130 (H.L.) 1130.

${ }_{119}$ Andrew Burrows, Remedies for Torts and Breach of Contract 414 (3rd ed. 2004).

${ }^{120}$ In making these claims, Weinrib's analysis sits uncomfortably with his argument, just discussed, that punitive damages in the second category in Rookes v. Barnard are actually restitutionary damages.

${ }^{121}$ Ernest J. Weinrib, Punishment and Disgorgement as Contract Remedies, 78 Chi.-Kent. L. Rev. 55, 84 (2003).

${ }^{122} I d$.

${ }^{123} \mathrm{Id}$.
} 
rare in the United Kingdom. ${ }^{124}$ But this point does little to insulate Weinrib from the present critique given that his theory extends to all of the jurisdictions with which we are concerned, and outside of the United Kingdom the award of punitive damages is much less confined. ${ }^{125}$ In the context of a universal theory, it is illegitimate to cherry pick the law of just one jurisdiction, especially when the law of the jurisdiction concerned differs markedly from that elsewhere.

\section{Rights theory}

The fact that punitive damages generally are available throughout the common law world is highly problematic for Stevens's theory. Stevens is alive to the challenge that they present. He acknowledges: "it may be objected that that punitive damages are ... inconsistent with a rights-based model of the law. If the courts are concerned to punish the defendant for his wrongdoing, it can be argued that this goes beyond mere vindication of the plaintiff's rights”. ${ }^{126}$ Stevens responds to this challenge by contending that punitive damages, and compensatory damages, too, are a form of damages that are substitutive for the right that is infringed. ${ }^{127}$ The idea is that "[t]he more outrageous the defendant's conduct, the greater the infringement of the right and the greater the substitutive award”. ${ }^{128}$ Stevens then draws his readers" attention to aspects of the law on punitive damages that are consistent with this way

\footnotetext{
124 "Punitive damages [are] a remedy of last resort": Kuddus v. Chief Constable of Leicestershire Constabulary, [2001] UKHL 29, [2002] 2 AC 122, para 63.

125 "[I]n other common law jurisdictions, in particular Australia, New Zealand, Canada and the United States, punitive damages have continued to flourish": Law Commission, Aggravated, Punitive and Restitutionary Damages, Report No 247 (1997) 104 n 567. This remark would now need to be qualified in relation to Australia in light of the later statutory changes in that jurisdiction: see Part IIC1 supra.

${ }^{126}$ Stevens, supra note 9, at 85 .

${ }^{127} \mathrm{Id}$.

${ }^{128} \mathrm{Id}$.
} 
of understanding them. Good illustrations (Stevens's not ours ${ }^{129}$ ) include the fact that punitive damages are paid to the victim (in most jurisdictions) rather than to, for example, the state $\mathrm{e}^{130}$ and the fact that the procedural and evidential protections conferred upon defendants that are found in criminal law proceedings are not generally given to tort defendants who are sued for punitive damages. These rules make sense if the focus of tort law is on the violation of the plaintiff's right.

However, as Stevens concedes, ${ }^{131}$ there are other rules governing the award of punitive damages that stand in the way of this interpretation of them. When these other rules are considered cumulatively, they show that punitive damages are not a species of substitutive damages. We note some of these rules here, not all of which are acknowledged by Stevens.

(1) It is well established that the defendant's wealth is a material factor to consider in determining the quantum of punitive damages. ${ }^{132}$ This fact contradicts Stevens's explanation of punitive damages. It shows that punitive damages are not driven by a concern to vindicate the plaintiff's right. The economic wealth of the defendant has nothing to do with the plaintiff's rights.

(2) The courts in awarding punitive damages take account of the need to deter the defendant and others from engaging in the conduct in question. ${ }^{133}$ This principle cannot be explained by a rights-based account of tort law. This is because it is aimed at incentivising the defendant and third-parties to act in particular ways rather than with ensuring that punitive damages vindicate a right enjoyed by the plaintiff.

\footnotetext{
${ }^{129}$ Id. at $86-87$.

${ }^{130}$ Cf. the position in some jurisdictions in the United States: see Dobbs, supra note 40, at 1075.

131 Stevens, supra note 9 , at 87.

132 See, e.g., John v. MGN Ltd, [1997] QB 586, 625 (C.A.); Restatement (Second) of Torts § 908, cmt e.

133 See, e.g., Broome v. Cassell \& Co Ltd, [1972] AC 1027, 1073 (H.L.).
} 
(3) The fact that, in the United Kingdom, punitive damages are available only if the case falls within one of the three categories identified in Rookes v. Barnard ${ }^{134}$ is a problem for Stevens's account of punitive damages. If, as he claims, they are awarded to vindicate the plaintiff's right that was infringed by the defendant, why are they available only in the three situations recognized in Rookes v. Barnard? Those are plainly not the only situations in which, if tort is about the vindication of rights, a plaintiff's right might be egregiously infringed.

(4) In all jurisdictions, the courts must exercise restraint both in deciding to award punitive damages (they are "a remedy of last resort" ${ }^{135}$ ) and, if the decision is made to award them, in determining their quantum. ${ }^{136}$ The existence of this constraint is inexplicable from a rights-based approach. If egregious violations of rights require a larger award of damages than would be provided by compensatory damages in order to vindicate the right, punitive damages should be available as of right whenever there is such a violation.

(5) Stevens's explanation cannot account for the fact that where the defendant has been punished by the criminal law (or by other means) in respect of the conduct about which the plaintiff complains, an award of punitive damages might be reduced or precluded for that reason. ${ }^{137}$ If the concern is with the vindication of the plaintiff's rights, the fact that the defendant has already been punished ought to be irrelevant.

(6) Stevens cannot explain the rules that apply where there are multiple plaintiffs who are deserving of an award of punitive damages. The law here is that the court should divide

\footnotetext{
134 [1964] AC 1129 (H.L.).

135 Kuddus v. Chief Constable of Leicestershire Constabulary, [2001] UKHL 29, [2002] 2 AC 122, para 63.

136 Rookes v. Barnard, [1964] AC 1129, 1227 (H.L.); Gray v. Motor Accident Commission, (1998) 196 CLR 1, para 20 (Aust H.C.).

137 Walker v. CFTO, (1987) 39 CCLT 121 (O.N.C.A.); AB South West Water Services, [1993] QB 507 (C.A.); Gray v. Motor Accident Commission, (1998) 196 CLR 1 (Aust. H.C.).
} 
the punitive damages awarded equally between the plaintiffs. ${ }^{138}$ This is inconsistent with Stevens's rights-based explanation of punitive damages. It means that only by chance will the quantum of the punitive award reflect the gravity of the violation of any given plaintiff's right.

As we have noted, Stevens concedes that the evidence in favor of his explanation of punitive damages is not "all one way". ${ }^{139}$ There are some aspects of the law on punitive damages that he can explain. However, there is a great deal more that he cannot explain. The clash between what the law is and his theory is significant. The simple truth is that unless the foregoing features of the law of punitive damages (several of which are not mentioned by Stevens) are disregarded, punitive damages cannot be brought within the scope of his rights theory. Allan Beever summed up the insurmountable obstacles that rights theorists face as a result of punitive damages when he said: "in awarding punitive damages, a court cannot be taken to be concerned with the rights of the plaintiff. The court is expressing condemnation of the defendant, but condemnation of the defendant does not imply vindication of the plaintiff”. ${ }^{140}$ We agree.

\section{Economic theory}

Posner explains punitive damages on the ground that they promote optimal deterrence. He writes: "Tort ... price[s] conduct that [it] wishes to discourage or at least regulate. The optimal price will sometimes exceed the harm to the victim”. ${ }^{141}$ Posner gives various illustrations of situations where he believes an award of punitive damages is required. He

\footnotetext{
138 Riches v. News Group Newspapers Ltd, [1986] 1 QB 256 (C.A.).

139 Stevens, supra note 9, at 87.

140 Allan Beever, The Structure of Aggravated and Punitive Damages, 23 OJLS 87, 99 (2003).

141 Posner, supra note 21, at 54.
} 
suggests, for instance, that punitive damages should be awarded where they are necessary to strip a defendant of a profit that he made as a result of the tort (that is, where the compensatory award is insufficient to eliminate the profit). He also argues that punitive damages are needed where the tort is “concealed” (Posner gives the example of a hit-and-run accident) and the probability of detection is consequently low. Where the probability of detection is low, punitive damages (or some other form of punishment, such as a criminal law sanction) are needed to ensure that the law sufficiently deters.

There are overwhelming difficulties with Posner's account. In the first place, he cannot explain why only the victim of a tort is entitled to sue for punitive damages. If the goal of awarding punitive damages is to ensure that people are optimally deterred, it is nonsensical to limit the right to sue for punitive damages to victims. The probability of a punitive award being made where one is required on efficiency grounds would be greatly increased if this constraint did not exist. In short, it is inefficient to permit only the plaintiff to bring proceedings for punitive damages. Beever notes that a possible reply to this point is that such a rule might provoke excessive litigation, and that a rule that permitted all and sundry to sue for such damages would therefore yield a net loss to society. ${ }^{142}$ However, the risk of excessive litigation is minimal given (1) the principle that the courts should proceed cautiously in awarding punitive damages; ${ }^{143}$ and (2) the many well-known legal devices that are in place to control excessive litigation. ${ }^{144}$ A second obstacle for Posner's account is the fact that, with the exception of some jurisdictions in the United States, it is permissible to insure against liability

\footnotetext{
142 Beever, supra note 140 , at 103.

143 See the text accompanying supra notes 135-136.

144 We have in mind here rules such as the loser-pays principle concerning legal costs (which obtains in most of the common law world), Part 36 offers under the Civil Procedure Rules (UK) (1998) and equivalents in other jurisdictions and restrictions on the ability of vexatious litigants to commence proceedings. We recognize that the loser-pays principle is not the default rule in the United States.
} 
to pay punitive damages. ${ }^{145}$ This rule regarding insurance is inefficient since the person who needs to be deterred will not be made to pay. It is therefore inconsistent with Posner's theory. Thirdly, Posner cannot explain the fact that, in the United Kingdom, punitive damages are, pursuant to Rookes v. Barnard, restricted to three categories of case. On his explanation, they should be available wherever they are needed to ensure that awards sufficiently deter.

\section{The Defense of Illegality}

\section{The law}

There is considerable divergence in the law regarding the defense of illegality in the common law world. In Australia, both common law and statutory illegality defenses exist. The common law defense will apply if permitting recovery would be inconsistent with the legislative intention expressed in the criminal law statute that the plaintiff contravened. ${ }^{146}$ The statutory defenses ${ }^{147}$ are, overall, far more potent. The precise shape that they take varies considerably from jurisdiction to jurisdiction, but it is generally true to say that they apply where the plaintiff was injured while committing a serious offence and the commission of the offence was causally connected to the damage that the plaintiff suffered. ${ }^{148}$ In Canada, the

${ }^{145}$ Lancashire County Council v. Municipal Mutual Insurance Ltd, [1997] QB 897 (C.A.) (holding that it is permissible to insure against liability to pay punitive damages at least where punitive damages are awarded on the basis of vicarious liability); Gray v. Motor Accident Commission, (1998) 196 CLR 1 (Aust. H.C.). In some parts of the United States, it is permissible to insure against liability to pay punitive damages while in others it is not: see Dobbs, supra note 40, at 1063 for the details.

146 Miller v. Miller, [2011] HCA 9, (2011) 242 CLR 446.

147 Civil Liability Act (NSW) §§ 54-54A (2002); Motor Accidents Compensation Act (SA) § 47A (1999); Criminal Code Act (Qld) § 6 (1899); Civil Liability Act (Qld) § 45 (2003); Civil Liability Act (SA) § 43 (1936); Civil Law (Wrongs) Act (ACT) § 94 (2002); Personal Injuries (Liabilities and Damages) Act (NT) $\S 10$; Transport Accident Act (Vic) § 40 (1986); Offenders (Legal Action) Act (WA) § 5 (2000).

148 The details are given in James Goudkamp, A Revival of the Doctrine of Attainder? The Statutory Illegality Defences to Liability in Tort, 29 Sydney Law Review 445 (2007). 
defense of illegality was severely confined by the landmark decision in Hall v. Hebert. ${ }^{149}$ Pursuant to that decision, the defense will apply only where it is necessary to deny recovery in order to preserve the coherence of the legal system. The principal situation where the defense applies is where the plaintiff seeks damages in respect of a criminal law penalty imposed on him. The law governing the defense in the United Kingdom is in a state of flux. ${ }^{150}$ However, speaking very generally, the defense applies in the same circumstances as it does in Canada ${ }^{151}$ and also where the defendant relies on his own illegality (or needs to rely on it) in order to recover. ${ }^{152}$ In the United States, illegality is not formally a defense, ${ }^{153}$ although the fact that the plaintiff was injured while acting illegally frequently will be relevant to other rules, most notably the doctrine of contributory negligence (or "comparative responsibility", as it is generally known there in those jurisdictions that have abolished the all-or-nothing rule).

149 [1993] 2 SCR 159 (S.C.C.). See also HL v. Canada (AG), [2005] SCC 25, [2005] 1 SCR 401; British Columbia v. Zastowny, [2008] SCC 4, [2008] 1 SCR 27.

${ }^{150}$ This is primarily due to the fact that a flurry of recent decisions at the ultimate appellate level regarding the defense do not really engage with each other: see Gray v. Thames Trains Ltd, [2009] UKHL 33, [2009] 1 AC 1339; Hounga v. Allen, [2014] UKSC 47, [2014] ICR 846; Stone \& Rolls Ltd v. Moore Stephens, [2009] UKHL 39, [2009] AC 1391; Les Laboratoires Servier v. Apotex Inc, [2014] UKSC 55, [2015] AC 430; Bilta (UK) Ltd (in liq) v. Nazir, [2015] UKSC 23, [2015] 2 WLR 1168. For an assessment of some of these authorities see James Fisher, The ex turpi causa principle in Hounga and Servier, 78 M.L.R. 854 (2015); James Goudkamp, The Doctrine of Illegality: a Private Law Hydra, 6 UK Supreme Court Yearbook 254.

151 The law in Canada was described in Gray v. Thames Trains Ltd, [2009] UKHL 33, [2009] 1 AC 1339 as adopting the "narrow rule". It was accepted in Gray that the narrow rule applies also in the United Kingdom. See further regarding Gray James Goudkamp, A Long, Hard Look at Gray $v$ Thames Trains Ltd in The Jurisprudence of Lord Hoffmann: A Festschrift for Leonard H Hoffmann ch 4 (Paul S. Davies \& J. Pila eds., 2015).

152 Tinsley v. Milligan [1994] 1 AC 340 (H.L.) is often regarded as the main decision promoting the reliance test. It was said in Hounga v. Allen, [2014] UKSC 47, [2014] ICR 846 para 30 that that test continues to carry "maximum precedential authority". There is also a statutory illegality defense in the United Kingdom s 329 of the Criminal Justice Act 2003 (UK). This defense is of fairly limited scope and we will leave it to one side in this article.

153 See Robert A. Prentice, Of Tort Reform and Millionaire Muggers: Should an Obscure Equitable Doctrine be Revived to Dent the Litigation Crisis?, 32 San Diego L. Rev. 53 (1995); J.H. King, Outlaws and Outlier Doctrines: The Serious Misconduct Bar in Tort Law, 43 Wm. \& Mary L. Rev. 1011 (2002). The leading hornbooks on tort law in the United States contain no section on illegality as a defense. 


\section{Corrective justice}

In a footnote in The Idea of Private Law Weinrib concedes that the illegality defense clashes with his corrective justice theory. Recall that corrective justice is bilateral in nature, in the sense that it is concerned equally with both parties. ${ }^{154}$ Rules, if they are to be explicable in terms of corrective justice, must therefore be bilateral too. It follows that the illegality defense is problematic for Weinrib because it focuses solely on the plaintiff rather than on the parties' relationship. As Weinrib puts it: "It is sometimes said ... that a plaintiff who was negligently injured while committing an illegal act cannot recover. This defense is inconsistent with corrective justice, because illegality as such is not relevant to the direct interaction of doer and sufferer". 155

The difficulty created by the illegality defense is most acute for Weinrib in the case of Australia and the United Kingdom, where the defense is relatively expansive. Weinrib might argue that the defense in Canada, which recognizes a much narrower version of the defense, is actually consistent with corrective justice. As noted, in Canada, the defense applies only when it is necessary to deny relief in order to preserve the coherence of the legal system. It might be thought that Weinrib can gain some mileage from this given the stress that he places on the law’s coherence. ${ }^{156}$ Weinrib suggests as much in the Idea of Private Law. ${ }^{157}$ However, it is doubtful that the law in Canada coheres with Weinrib's theory. The fact remains that the defense, even in Canada, is triggered by a unilateral consideration, namely, the plaintiff's offence. Furthermore, the need to maintain coherence in the law generally is also something that falls outside of the immediate interaction between the parties.

\footnotetext{
154 Weinrib, supra note 1 , at 120-121.

${ }^{155} \mathrm{Id}$. at $169 \mathrm{n} 53$.

156 See, especially, id. at 11-16.

157 Id. 169 n 53.
} 
Overall, Weinrib is correct to see the illegality defense as posing a significant difficulty for his theory of tort law. He does not offer a sustained argument in an attempt to explain away the difficulty, and it is doubtful whether the difficulty that the defense presents can be explained away. The clash between Weinrib’s theory and tort law on account of the illegality defense is unresolved.

\section{Rights theory}

Stevens does not discuss the illegality defense in his Torts and Rights beyond saying that he does not need to address it because it is not a rule that is specific to tort law. ${ }^{158}$ It is true that the defense is available throughout the law generally. ${ }^{159}$ However, we do not believe that it justifiably can be ignored by one who is offering a universal theory of the whole of tort law. This is primarily because in many jurisdictions the rules that govern the defense of illegality take on a distinct shape in the tort setting. The rules that control the defense in this sphere are often very different from those that apply in, for example, the contract law or trusts setting. ${ }^{160}$ We are also of the view that the defense cannot justifiably be disregarded given its obvious and considerable significance in modern tort law. Ultimate appellate courts in several of the jurisdictions with which we are concerned have considered it repeatedly in recent years, ${ }^{161}$ and it has caught the interest of several legislatures. ${ }^{162}$

Stevens, in our view, needs to account for the illegality defense, given his mission to explain all of tort law. We believe that he would be unable to do so. We have been influenced

\footnotetext{
158 Stevens, supra note 9, at 304-305.

159 "[The defense] applies across the board": Vellino v. Chief Constable of Greater Manchester, [2001] EWCA Civ 1249, [2002] 1 WLR 218, para 44.

160 Compare, e.g., the principles developed in the trusts context in Tinsley v. Milligan, [1994] 1 AC 340 (H.L.) with those expounded in the negligence case of Gray v. Thames Trains Ltd, [2009] UKHL 33, [2009] 1 AC 1339.

161 See, for example, the cases mentioned in supra note 150 in relation to the United Kingdom.

162 See supra notes $147,152$.
} 
in this regard by a paper that Stevens himself wrote regarding the doctrine of contributory negligence. Stevens's position in that paper, which is also written from a rights-based perspective, is that contributory negligence should not be an answer to liability in tort. ${ }^{163}$ The basic reason given in support of that contention is that the plaintiff's conduct, so long as it is not an intervening cause, is irrelevant to whether the plaintiff's rights have been infringed, and because tort law is fundamentally concerned with whether the plaintiff's rights have been infringed, contributory negligence should be irrelevant. In Stevens’s words, “The reason why contributory fault should not be a defense is that the risks I run in relation to my own interests are nobody’s concern but mine.” ${ }^{64}$ Stevens correctly surmises that if what matters is the fact that the plaintiff's rights have been violated (or, put differently, that the defendant has breached his duty), one would expect the plaintiff's conduct to be immaterial, provided that it is not such that no right of his has been breached. This reasoning applies mutatis mutandis to the defense of illegality. If the focus is on the plaintiff's rights, it should not matter whether the plaintiff was acting legally or illegally. But that is not the law. Stevens's theory is, therefore, unable to account for the defense of illegality. This is a major difficulty for it.

A possible escape route available to Stevens is to argue that, when the illegality defense applies, the plaintiff forfeits his right. According to this line of reasoning, when the illegality defense is engaged, there is no right that needs vindicating, and it is therefore appropriate that recovery is denied. This is a rights-based account of the illegality defense. This explanation of the defense looks most plausible where the defense operates, as it does in some jurisdictions in certain contexts, not as a true defense but as a rule that prevents one or more of the elements the cause of action in which the plaintiff sues from being satisfied. ${ }^{165}$ Where the

${ }^{163}$ Robert Stevens, Should Contributory Fault be Analogue or Digital? in Defences in Tort § 13 (Andrew Dyson, James Goudkamp \& Fred Wilmot-Smith eds., 2015).

${ }^{164}$ Id. 253.

165 See, e.g., Joyce v. O’Brien, [2013] EWCA Civ 546, [2014] 1 WLR 70, where the plaintiff's illegality prevented the causation element of the action in negligence from being satisfied. 
doctrine of illegality functions in this way, it may well be that the plaintiff, when the "defense" is triggered, has no right. However, it is clear that in all of the major common law jurisdictions the doctrine of illegality functions in at least some contexts as a true defense, and does not merely strike at the elements of the plaintiff's action. ${ }^{166}$ This is so most explicitly in Canada, where it has been made stated explicitly at the highest level that illegality works exclusively as a defense and not, for example, as a principle that denies the existence of a duty of care. ${ }^{167}$ When the doctrine of illegality functions as a true defense, this forfeiture argument runs into formidable difficulty. This is because it depends upon the shaky proposition that a defendant ceases to be under a legal duty when a defense is enlivened. The accuracy of this proposition is dubious, and this is particularly so in relation to defenses such as illegality.

If one is under a legal duty, one has reasons supplied by the law (that is to say, reasons additional to whatever reasons exist independently of the law) not to act in a way that is contrary to that duty. It is strongly arguable that those reasons (and hence the duty) continue to exist, even if a defense applies. The point can be nicely illustrated by way of the defense of defensive force. ${ }^{168}$ Suppose that defensive force is used to kill a terrorist who was about to detonate a bomb the blast from which would have killed many people. Killing the terrorist was obviously justifiable, at least if he could not have been prevented from exploding the bomb by less drastic means. However, equally plainly, the fact that the killing of the terrorist was justifiable does not mean that are no reasons not to kill the terrorist. We have reasons not to kill people even if they are terrorists who are about to murder many innocent people. What we are dealing with here is a situation where the reasons not to kill the terrorist were outweighed by reasons in favor of killing the terrorist. Because the reasons not to kill the

\footnotetext{
${ }^{166}$ The details are given in James Goudkamp, Tort Law Defences 126-127 (2013).

${ }^{167}$ Hall v. Hebert, [1993] 2 SCR 159 (S.C.C.).

${ }^{168}$ The illustration is taken from Kenneth Campbell's important paper on conflicts of practical reasons: Kenneth Campbell, Offence and Defence in Criminal Law and Justice: Essays from the W.G. Hart Workshop, 198683 (Ian H. Dennis ed., 1987). See also John Gardner, Offences and Defences: Selected Essays in Philosophy of Criminal Law $§ 5$ (2007), on whose analysis the discussion here also draws.
} 
terrorist remain intact, so too must the duty that gave rise to them, even though a defensive force defense applies. This reasoning applies a fortiori where a non-justificatory defense is in play. Reasons created by torts to refrain from committing particular acts clearly remain intact (and hence the defendant still owes a duty) when a non-justificatory defense, such an immunity or illegality, applies. For instance, a person who is entitled to diplomatic immunity obviously has reasons created by the law not to commit a battery despite his immunity. He is still under a duty not to strike people. The same is true where the defense of illegality is enlivened. This means, of course, that offenders continue to have rights despite their offending. Accordingly, this forfeiture argument is of no assistance to Stevens.

\section{Economic theory}

The defense of illegality is an obvious and significant problem for Posner's account. Tort law, Posner claims, imposes liability where the defendant is the cheapest loss avoider, this being the most efficient rule. However, in Australia and the United Kingdom the defense may prevent liability from arising where liability should be imposed according to this criterion. Suppose that D acts unreasonably (according to the Learned Hand formula) and causes injury to $\mathrm{P}$ as a result. The efficient rule is for $\mathrm{D}$ to be held liable. However, in Australia and the United Kingdom, if the plaintiff was injured while acting illegally, he will be unable to recover if (in the case of Australia) his illegality was causally connected to the damage about which he complains or (in the case of the United Kingdom) he has to rely on his illegality in order to establish his cause of action. There seems to be a significant clash between the law in these jurisdictions and Posner's theory. A reply available to Posner is that the illegality defense deters criminal behavior by the plaintiff, and that, even though it means that the defendant is not deterred by tort law where it applies, there is a net gain in societal wealth. 
However, this response is implausible for several reasons. ${ }^{169}$ First, plaintiffs are unlikely to even know about the illegality defense and therefore cannot be deterred by it. As Millett LJ observed in Tribe v. Tribe, the type of people who commit offences that are likely to trigger the defense are "unlikely to be ... studious reader[s] of the law reports". ${ }^{170}$ Secondly, even if a given plaintiff does know about it, it is doubtful that he would be deterred by it. If the risk of being both punished by the criminal law and suffering serious personal injury in the course of an illegal enterprise is insufficient to deter the plaintiff, it is hardly likely that the risk that the plaintiff might be denied a remedy in tort that he may have otherwise enjoyed will make a difference to his decision-making process. Thirdly, even if, contrary to what we have just suggested, the illegality defense may influence behavior, it may be just as likely to encourage offending as it is to deter it. ${ }^{171}$ Suppose that $\mathrm{P}$ and $\mathrm{D}$ steal a car and that $\mathrm{P}$ is injured as a result of D's negligent driving. $\mathrm{P}$ is unlikely to be able to recover damages from $\mathrm{D}$ in either Australia or the United Kingdom. ${ }^{172}$ This makes such joint illegal enterprises cheaper for D than would otherwise be the case.

Can Posner explain the illegality defense in Canada? As noted earlier, the main situation where the defense applies in Canada is where the plaintiff sues in respect of the loss that he suffers as a result of having a criminal law penalty imposed on him. It is efficient for the defense to apply in this context. Assuming that the criminal law produces the optimal gain to society in terms of wealth by imposing a sanction, it must be inefficient for tort law to reverse what the criminal law has done. And even if the criminal law has produced a sub-optimal result, it is probably inefficient to have a second set of proceedings to correct the criminal law's errors (the efficient thing to do in this situation would be for the criminal law to correct

\footnotetext{
${ }^{169} C f$. the view of the Law Commission, which argued that the illegality defense can deter offending: Law Commission, The Illegality Defence: A Consultative Report, Consultation Paper 189 (2009) at [2.19]-[2.23].

${ }^{170}$ [1996] Ch 107, 113-114 (C.A.).

${ }^{171}$ This point has often been made: see, e.g., Tinsley v. Milligan, [1994] 1 AC 340, 368 (H.L.) 368.

${ }^{172}$ Miller v. Miller, [2011] HCA 9, (2011) 242 CLR 446 (Aust H.C.); Joyce v. O’Brien, [2013] EWCA Civ 546, [2014] 1 WLR 70.
} 
its own mistakes via the appellate apparatus or for the criminal law to be changed so that it produces an efficient outcome). Nothing needs to be said here about the situation in the United States where no formal defense of illegality exists.

\section{E. The Rule in Rylands v. Fletcher and its Descendants}

\section{The law}

The rule established by the nineteenth century case of Rylands v. Fletcher ${ }^{173}$ has evolved in different ways in different parts of the common law world. In the United States, it came to be understood as establishing a principle of strict liability that applies only to ultrahazardous activities. ${ }^{174}$ In the United Kingdom, the rule is not confined to untrahazardous activities ${ }^{175}$ although it does impose strict liability. In Canada, the relevant law - at least in the common law provinces - is substantially the same as that in the United Kingdom. ${ }^{176}$ In Burnie Port Authority v. General Jones Pty Ltd, ${ }^{177}$ the High Court of Australia subsumed the rule in Rylands v. Fletcher within the law of negligence. The Court remarked: “The rule in Rylands v. Fletcher, with all its difficulties, uncertainties, qualifications, and exceptions, should now be seen ... as absorbed by the rules of ordinary negligence”. ${ }^{178}$ The rule does not, therefore, exist as a discrete cause of action in Australia, and situations in which it would have applied are determined by the tort of negligence.

\footnotetext{
173 (1865) 3 H \& C 774; 159 Eng. Rep. 737 (Exch), affirmed in (1868) LR 3 HL 330 (H.L.).

174 In successive Restatements of Tort Law the rule spawned by Rylands $v$. Fletcher has been referred to as one concerning "ultrahazardous" and "abnormally dangerous" activities: Restatement of Torts §§ 519-524; Restatement (Second) of Torts $\S 520$; Restatement (Third) of Torts: Liability for Physical and Emotional Harm $\S 20$.

175 Consider Read v. J Lyons \& Co Ltd, [1947] AC 156, 181-182 (H.L.) per Lord Simons.

176 See, e.g., Tock v. St John's Metropolitan Area Board, [1989] 2 SCR 1181, 1189-1190 (S.C.C.); Aldridge v. Van Patter, OR 595 (H.C.); Smith v. Inco Ltd, [2011] ONCA 628, (2011) 107 OR (3d) 321.

177 (1994) 179 CLR 520 (Aust. H.C.).

178 (1994) 179 CLR 520, 556 (Aust. H.C.) per Mason CJ and Deane, Dawson, Toohey and Gaudron JJ.
} 


\section{Corrective justice}

The rule in Rylands v. Fletcher, which exists in one guise or another in Canada, the United Kingdom and the United States, clashes with Weinrib's theory by virtue of the fact that it imposes strict liability. According to Weinrib, strict liability is incompatible with his theory since strict liability affords preferential treatment to plaintiffs whereas corrective justice treats the parties as equals. ${ }^{179}$ This clash between the rule in Rylands v. Fletcher and corrective justice has not escaped Weinrib's attention, and he seeks to show that the clash is merely apparent rather than real. He contends that the rule in Rylands v. Fletcher is "an extension, not a denial, of the fault principle”. ${ }^{180}$ He offers three arguments in this connection (none of which has, to the best of our knowledge, been properly tested by the existing literature). The first is that the rule in Rylands $v$. Fletcher merely "limit[s] rather than eliminate[s] the relevance of culpability”. ${ }^{181}$ This is because, he says, some of the defenses that are available in relation to the tort "show... that culpability is still operative." ${ }^{182}$ Weinrib identifies the defenses of act of God, vis major and act of third party. The second argument is that the rule continues the idea accepted by the law of negligence that the riskier the activity the greater the amount of care that is needed. Weinrib claims that at some point the activity is so risky that a "lack of care can be imputed from the very materialization of the risk". ${ }^{183}$ The rule in Rylands $v$. Fletcher is said to constitute the law's determination of the location of that point. The third argument is that the rule merely relieves "the plaintiff of the need to locate the specific faulty act” and that it cannot be implied from the fact that the activity in question was not an

\footnotetext{
${ }^{179}$ Weinrib, supra note 1 , at 177-179.

180 Id. at 188.

${ }^{181}$ Id. (footnote omitted).

${ }^{182} \mathrm{Id}$.

$183 \mathrm{Id}$.
} 
unlawful activity that "all of the defendant's acts within the activity were faultless." ${ }^{184}$ We see difficulties in all of these arguments, which we will mention in a moment. However, before doing this, we want directly to lock horns with Weinrib's overarching contention that the rule in Rylands v. Fletcher is an extension of the fault principle and does not, properly understood, impose strict liability. The simple fact is that the authorities preclude this interpretation. The courts have stressed repeatedly that the liability regime instantiated by the rule is strict. For example, in Cambridge Water Co Ltd v. Eastern Counties Leather plc Lord Goff (who delivered a speech with which the other Law Lords all agreed) said that "the principle is one of strict liability”. ${ }^{185}$ Similarly, the California Court of Appeals in Pierce v. Pacific Gas \& Electric Co said that "[t]he doctrine of ultrahazardous activity provides that one who undertakes an ultrahazardous activity is liable to every person who is injured as a proximate result of that activity, regardless of the amount of care he uses". ${ }^{186}$

Weinrib's overarching assertion is untenable given the authorities, but it is nonetheless worth understanding precisely why the arguments that he offers in support of it are unconvincing. His first argument is that culpability is made relevant by certain defenses to liability arising under the rule in Rylands v. Fletcher. The main problem with this argument is that, even if it is accepted, it would not follow that the rule in Rylands $v$. Fletcher is consistent with corrective justice. In order to demonstrate that the rule in Rylands $v$. Fletcher complies with corrective justice, it is necessary to show, relevantly, not only that it imposes liability based on fault, but also that the fault requirement is such that the parties are treated as equals. Merely because a given liability rule is based on fault does not mean that it complies with corrective justice, which is a point that Weinrib himself makes

\footnotetext{
184 Id. at 189.

185 [1994] 2 AC 264, 302 (H.L.)

186166 Cal App 3d 68, 85 (Ct App, 1985) (emphasis added). That liability is strict in respect of the harm caused by abnormally dangerous activities across much of the United States is confirmed in the Restatement (Third) of Torts: Liability for Physical and Emotional Harm § 20.
} 
elsewhere in The Idea of Private Law. ${ }^{187}$ Critically for present purposes, the fault-based defenses to liability arising under the rule in Rylands $v$. Fletcher mentioned by Weinrib do not result in the liability regime created by the rule treating the parties as equals. This is because the defenses are relevant only in limited situations. They will not necessarily apply in every situation (or even in most situations) in which the elements of the cause of action in Rylands v. Fletcher are present and the defendant is faultless. A good illustration of the point is Jones $v$. The Festiniog Railway Co. ${ }^{188}$ In this case, the defendants were held liable under the rule in Rylands $v$. Fletcher in respect of sparks that escaped from a locomotive and that caused damage to the plaintiff's land. Crucially, the defendants were held liable even though it was shown that they had taken all reasonable care and were hence faultless. ${ }^{189}$ No defense applied. Another example is Humphries v. Cousins. ${ }^{190}$ In this case, sewage escaped from the defendant's land through no fault of the defendant and damaged the plaintiff's land. No defense was engaged, and the faultless defendant was held liable under the rule in Rylands v. Fletcher. Many further illustrations could be given without any difficulty. The short point to take away from these cases is that, contrary to Weinrib's analysis, the mere existence of fault-based defenses does not mean that the rule in Rylands $v$. Fletcher treats the parties as equals. Rather, notwithstanding the existence of these defenses, the rule generally affords plaintiffs preferential treatment, contrary to Weinrib’s corrective justice theory of tort law.

Weinrib’s second argument in support of the proposition that the rule in Rylands $v$. Fletcher is fault-based - that fault can be imputed to the defendant who is held liable under the rule given the dangerousness of the activity that led to the escape - is also unconvincing.

\footnotetext{
187 Weinrib, supra note 1, at 177-178 (discussing the incompatibility of subjective forms of fault with corrective justice).

188 (1867-68) LR 3 QB 733 (Q.B.D.).

189 (1867-68) LR 3 QB 733, 736 (Q.B.D.) 736.

190 Humphries v. Cousins (1877) 2 CPD 239 (1877) (Common Pleas).
} 
Weinrib simply does not tell us why he thinks it is right to impute fault to a defendant who commits the tort in Rylands v. Fletcher. However, even if he is correct in making this claim, this would not mean that the rule in Rylands $v$. Fletcher is consistent with corrective justice. Constructive fault is not the same thing as actual fault, and only a rule that is sensitive to actual fault treats the parties as equals. To say that a defendant who is not at fault should be deemed to be at fault does nothing to redress the favorable treatment that the rule in Rylands v. Fletcher affords plaintiffs.

Weinrib’s third argument for characterising the rule in Rylands v. Fletcher as imposing fault liability - that the rule merely relieves the plaintiff of the need to isolate a specific faulty act in a wider activity - holds no water either. Simply because the plaintiff in proceedings under the rule in Rylands $v$. Fletcher does not have to prove that the defendant in committing a specific act was at fault does not mean that the defendant is at fault. There may be nothing faulty in the conduct of a defendant who commits the tort in Rylands $v$. Fletcher. ${ }^{191}$ The fact remains, therefore, that liability under the rule in Rylands $v$. Fletcher may be attached to faultless conduct.

For the foregoing reasons, Weinrib’s attempt to paint the rule in Rylands v. Fletcher as being based on fault is unsuccessful. The rule in its various manifestations in Canada, the United Kingdom and the United States is one of strict liability and, as such, is incompatible at a fundamental level with Weinrib’s corrective justice theory.

\section{Rights theory}

There is significant and growing theoretical support for notion that the rule in Rylands $v$. Fletcher does not involve any wrong and hence no violation of a right. The logic

${ }^{191}$ See the cases mentioned in the text accompanying supra notes 185-186. 
underpinning this view is that a person may be held liable for this tort despite the fact that, in accumulating, say, water in a reservoir, he complied with all relevant standards of behavior. As Peter Jaffey puts it: “[a] claim under the rule in Rylands $v$. Fletcher ... arises from a primary liability relation that allocates to $\mathrm{D}$ the risk of loss to [P] without imposing on him a duty to prevent it”. ${ }^{192}$ If this interpretation of the rule is correct, the rule presents a significant problem for Stevens's theory. This is because it contradicts Stevens's mantra that torts are the infringements of rights.

Stevens does not say whether he agrees with this understanding of the rule in Rylands $v$. Fletcher, but he tries in two ways to deal with the difficulty that the rule causes for his theory. He suggests, first, it is an anomaly; and, secondly, that it should be regarded as a subset of the law of private nuisance. ${ }^{193}$ Leaving to one side the fact that these claims are probably irreconcilable, ${ }^{194}$ neither one rescues his theory from the problem of fit that the rule presents. It is not altogether clear what Stevens means when he describes the rule in Rylands $v$. Fletcher as an "anomaly". If he means by this that the rule ought never to have been created, he is making a prescriptive claim. For the reasons given earlier, ${ }^{195}$ such claims cannot rescue explanatory theories. They involve arguing that the data should be changed so that it fits the theory, whereas theories that seek to explain the law (which is how Stevens describes his theory) must take the law as it exists. If, by contrast, what Stevens means by describing the

\footnotetext{
192 Peter Jaffey, Liabilities in Private Law, 14 Legal Theory 233, 240 (2008). Other theorists who support this interpretation of the rule include Goldberg and Zipursky, Torts as Wrongs, supra note 28, at 951 and McBride and Bagshaw, supra note 99, at 468.

193 Stevens, supra note 9, at 299. The implicit assumption made by Stevens in presenting this claim is that the tort of private nuisance is consistent with his rights theory. Stevens does not offer a sustained account of why he thinks that private nuisance is so explicable; he merely refers to the fact that it centres on proprietary right: Stevens, supra note 9 , at 63.

194 If the rule in Rylands $v$. Fletcher is simply a subset of the law of private nuisance, and the law of private nuisance is consistent with Stevens's theory, then there would be no reason for him to see the rule in Rylands $v$. Fletcher as anomalous.

195 See Part IIB2 supra.
} 
rule in Rylands $v$. Fletcher as an anomaly is that it is an outlier within tort law ${ }^{196}-$ and an outlier because it affords the plaintiff a cause of action without the defendant having breached any ex-ante private right held by the plaintiff against the defendant - then, again, he is on shaky ground. This is so because there is nothing particularly unusual (still less unique) in tort law affording a cause of action in the absence of an ex-ante private right on the part of the plaintiff. Many other torts do likewise such as the tort of causing loss by unlawful means, the dependency action afforded by the Fatal Accidents Act 1976 (UK), ${ }^{197}$ the action for inducing breach of contract, ${ }^{198}$ the action created by the Congenital Disabilities (Civil Liability) Act 1976 (UK), ${ }^{199}$ and the tort of public nuisance. ${ }^{200}$ Given these actions, it is implausible to contend that the rule in Rylands $v$. Fletcher is an outlier or in any way unique in constituting a tort that is not animated by the infringement of a private right held by the plaintiff.

196 This seems to be how Goldberg and Zipursky understand the rule. They describe the rule as a "sui generis" cause of action: Goldberg and Zipursky, Torts as Wrongs, supra note 28, at 952.

${ }^{197}$ In Torts and Rights, Stevens rightly acknowledges that the tort of causing loss by unlawful means and the dependency action created by fatal accidents legislation are incompatible with his account of the law (Stevens, supra note 9, at 188-190 and 174 respectively). (The former is inconsistent with his theory because a plaintiff has no right good against a defendant to trade or economic welfare, and the latter clashes because dependency claims are parasitic upon the infringement of a right held by the deceased rather than the plaintiff.) Stevens attempts to mitigate the difficulty that these actions pose by offering reasons to tolerate the results that they produce. In relation to the unlawful means tort, Stevens argues that the action can be justified because it prevents the plaintiff from using third parties as a means to his own ends (id. at 188). In relation to dependency action provided for by the 1976 Act, he argues that allowing dependants to sue results in a closer approximation to the wrong not having been committed than would be achieved than if the award accrued to the estate (id. at 176). Even if these reasons are convincing, in neither case do they have anything to do with the plaintiff's rights. These manoeuvres qua attempts to rescue his rights analysis from the difficulties presented by these actions are therefore mere distractions. They do nothing to change the fact that both actions are incompatible with his theory.

${ }^{198}$ In relation to the action for inducing breach of contract, Stevens argues - contrary to what the House of Lords held in OBG Ltd v. Allan, [2007] UKHL 21, [2008] 1 AC 1, paras 8, 45-64, 270, 302, 320 - that the tortfeasor is liable not on the basis of the accessory liability but rather on the basis of an ex-ante "accessory right" that we all have "good against everyone else that they do not induce the infringement of the contractual right[s] we hold": Stevens, supra note 9, at 281. So, for Stevens, what the House of Lords were happy to treat as a mere principle of tortious liability is better seen as a tort strictu sensu. This interpretation is unavailable in the wake of the decision in $O B G$.

199 Stevens admits that the Congenital Disabilities (Civil Liability) Act (UK) (1976) confers an action where there is no right. He writes "that the plaintiff had no legal personality and consequently no rights at the time of the tort”: id. at 185. Stevens then discusses the history of the action and its scope. None of this has any relevance to his rights theory, and consequently does nothing to explain away the difficulty that this action presents.

${ }^{200}$ So far as public nuisance is concerned, Stevens admits (id. at 186-189), rightly, in our view, that many of the cases in this area are incompatible with his rights account. The major difficulty that Stevens sees with the cases is that they lend support to the view that the plaintiff must suffer loss over and above that incurred by the public generally in order to sue. 
Stevens's second argument - that the rule in Rylands v. Fletcher has been subsumed within the law of private nuisance - proceeds on the assumption that the law of private nuisance is compatible with his theory. Stevens is certainly not alone in suggesting that the rule in Rylands v. Fletcher is part of the law of private nuisance. Statements to this effect have often been made in the United Kingdom, including at the ultimate appellate level. ${ }^{201}$ However, even if the action has been subsumed within the law of private nuisance in the United Kingdom, which is something that is hotly debated, ${ }^{202}$ this has plainly not happened elsewhere in the common law world. In Canada, for example, the rule in Rylands v. Fletcher and the action in private nuisance are separate. ${ }^{203}$ It is also noteworthy that the Reporters of the Restatement (Third) of Torts: Liability for Physical and Emotional Harm regard the law of private nuisance as independent of the ultrahazardous activities rule (that is, the American descendant of the rule in Rylands v. Fletcher). While liability may arise in both fields simultaneously, no suggestion can be found in the Restatement that the bases of liability have been merged. ${ }^{204}$ Accordingly, even if Stevens's claim that the rule in Rylands v. Fletcher is part of the law of private nuisance is an accurate description of the position in the United Kingdom, Stevens is still unable provide a compelling universal theory of tort law. ${ }^{205}$

201 See, e.g., Cambridge Water Co Ltd v. Eastern Counties Leather plc, [1994] 2 AC 264, 304 (H.L.) ("the rule in Rylands $v$. Fletcher was essentially concerned with an extension of the law of nuisance to cases of isolated escape” per Lord Goff); Transco plc v. Stockport MBC, [2003] UKHL 61, [2004] 2 AC 1, para 9, 52, 92 (2004).

202 See, e.g., Donal Nolan, The Distinctiveness of Rylands v. Fletcher, 121 LQR 421 (2005) and John Murphy, The Merits of Rylands v. Fletcher, 24 OJLS 643 (2004).

${ }^{203}$ In Smith v. Inco Ltd, [2011] ONCA 628, (2011) 107 OR (3d) 321, the Ontario Court of Appeal acknowledged the way things had developed in the United Kingdom in Cambridge Water and Transco. However, it stuck steadfastly to the distinction drawn between the two actions in by the Supreme Court of Canada in Tock v. St John's Metropolitan Area Board, [1989] SCR 118, paras 13-14 (S.C.C.). The court in Smith said (at para 68): "In Canada, Rylands v. Fletcher has gone largely unnoticed in appellate courts in recent years. However, in 1989 in Tock, the Supreme Court of Canada unanimously recognized Rylands v. Fletcher as continuing to provide a basis for liability distinct from liability for private nuisance or negligence”.

204 See, e.g., Restatement (Third) of Torts: Liability for Physical and Emotional Harm § 20, cmt c, where private nuisance is contrasted with the strict liability rule for ultrahazardous activities.

205 Another attempt to relocate the rule in Rylands $v$. Fletcher that might conceivably be invoked in order to rescue Stevens's theory is to contend that the rule is not part of tort law at all, and that it falls within another category of civil liability. This is how the rule is classified by, for example, McBride and Bagshaw, supra note 99, at 470. Their logic would appear to be as follows: (1) torts are wrongs that involve the breach of an ex-ante duty; (2) the cause of action minted in Rylands $v$. Fletcher does not fit this pattern since it does not 


\section{Economic theory}

In contrast to the theorists so far considered, Posner is considerably more at ease with the rule in Rylands v. Fletcher (or, more accurately, the American version of that rule concerning ultrahazardous activities). Writing with Landes, he maintains that the ultrahazardous activities rule is mandated "where achieving optimal accident avoidance requires altering the defendant's activity rather than his care or the plaintiff's activity or care” ${ }^{206}$ In such circumstances, “a rule of strict liability makes economic sense”. ${ }^{207}$ Posner further argues that the tort of negligence would not offer an adequate form of regulation in such circumstances. In his famous article, “A Theory of Negligence”, Posner wrote: ${ }^{208}$

There is a serious limitation of the negligence system as a method of optimizing the allocation of resources to safety... [so the courts] carved an important exception to the standard of negligence for ultrahazardous activities such as blasting. Those are by definition activities where unavoidable accident costs are great, and therefore where one is most likely to find that an alternative method of achieving the same result (digging instead of blasting) is cheaper when unavoidable accident costs are taken into account. A rule of strict liability - the rule applied to activities classified as ultrahazardous - compels them to be taken into account.

Given this stance, Posner cannot explain the law in all of the jurisdictions with which we are concerned. For in Australia, ultrahazardous activities are governed by the tort of negligence

require the breach of an ex-ante duty; hence (3) the rule in Rylands v. Fletcher is not a tort. Because McBride and Bagshaw are not our target theorists for the purposes of this article, and because their relevant comments are very brief, we will not engage with their analysis.

206 Landes and Posner, supra note 14, at 107.

207 Id. at 111.

${ }^{208}$ Richard A. Posner, A Theory of Negligence, supra note , at 76. 
(into which body of law the rule in Rylands v. Fletcher was subsumed, as noted earlier). So, although Posner's account may chime with the rules in the Canada, the United Kingdom and the United States, ${ }^{209}$ he is unable to accommodate the Australian position given that, on his account, ultrahazardous activities require regulation by way of a strict liability rule. On the assumption that Posner is right here - that is, that he is correct to suggest that there is "a serious limitation of the negligence system" in cases of this kind - the law in Australia is inefficient.

\section{F. Conclusion}

The theories of tort law that we have considered purport to explain tort law throughout the common law world, as we demonstrated by offering at the outset of this article explicit quotations or other very clear evidence from the writings of the authors of the theories in question. It has been argued that they do not achieve this goal when tested against the evidence in Australia, Canada, the United States and the United Kingdom. Five major areas of difficulty were discussed, namely, (1) the breach element of the action in negligence, (2) the law governing the recognition of a duty of care in respect of pure economic loss, (3) punitive damages, (4) the defense of illegality and (5) the rule in Rylands v. Fletcher and its descendants. While the theories in question can sometimes explain the law in relation to some of these rules in some of the jurisdictions in question, when looked at as a whole, these five important areas of tort law reveal a wide gulf between the claims made about tort law by these

\footnotetext{
${ }^{209}$ This is matter upon which he has himself remarked: "The Restatement's definition of ultrahazardous activities ... coincides with the economic principles that make strict liability the preferred liability rule": Landes and Posner, supra note 14, at 112. Certainly, the Restatement (Second) of Torts $§ 520$ states that the relevant factors governing the ultrahazardous activities rule include the very high expected accident costs, as well as the opportunity that the defendant had either to relocate, or to desist from engaging in the specific activity altogether.
} 
theories and the actual state of the law. Because of the size of this gulf, the theories concerned are not, contrary to what their proponents contend, satisfactory universal theories of tort law.

\section{OBJECTIONS TO THE ANALYSIS}

The main conclusion of this article has just been summarized. In this final section we consider several objections that are of a general nature that might be made against our analysis. Our aim here is to show that these objections do not hit home.

(1) Have the theories wrongly been seen as being without value? It might be argued that we have failed to notice the value in the theories that we have considered. We do not deny that the theories make important points or that they are obviously very valuable contributions to tort law scholarship. For example, Weinrib's writings raised the consciousness of private lawyers generally to some major shortcomings of functionalist (or, more specifically, law-and-economics) accounts of tort law. In a similar vein, Stevens's theory has done much to expose the inexplicability of torts that are actionable per se on a loss-based view of the law of torts. Nothing that we have said should be taken as suggesting that the theories in question have not significantly advanced our collective understanding of tort law. They all undoubtedly provide compelling accounts of sizeable parts of tort law, both within specific jurisdictions and across jurisdictions. The case that we have tried to make in this article is simply that the theories in question are unconvincing in so far as they are presented as universal theories of tort law.

(2) Have aspects of the law that the theories can explain been overlooked? It might be suggested that we have not really noted aspects of tort law across common law jurisdictions that the theories in question can explain. It is true that this has not been done. But that is not our mission. Indeed, we concede that the theories are capable of 
accounting for important parts of tort law in more than one jurisdictions. If they could not do this, it would not be worth subjecting the theories to sustained treatment; they would instead be discarded swiftly as self-evidently implausible. It follows that any suggestion that we have not taken seriously the strengths of the theories would be misconceived. Instead, it is precisely because we take seriously their strengths that we have thought it necessary to explore their weaknesses.

(3) Are the theories really explanatory theories? The theories under consideration have been criticized in this article on the basis that they do not accurately explain the law. It might be argued that we are mistaken in reading the theories as explanatory. Several scholars contend that some of the theories in question are instead interpretative ${ }^{210}$ (and others say that they are ultimately prescriptive ${ }^{211}$ ). However, even if the theories are properly labelled as interpretive, we do not think that that would have any implications for our analysis, for at least three reasons. First and foremost, it is crystal clear that, regardless of the label that is used that the very theorists on whose work we have focused have battled hard to prove that their theory provides the best fit of the law. It is beyond serious argument that the great bulk of their relevant writings (and certainly those of their writings with which we are concerned for the purposes of this article) are aimed at showing that the law conforms to their account of it. We went to considerable

${ }^{210}$ See, e.g., Allan Beever \& Charles Rickett, Interpretive Legal Theory and the Academic Lawyer, 68 MLR 320 (2005) (arguing that Weinrib's corrective justice theory should be understood as an interpretive theory).

${ }^{211}$ See, e.g., Stapleton, supra note 25, 1532 (suggesting that Goldberg and Zipursky's "project is a normative one”). See also at 1562. In his later work, Weinrib has exhibited a preparedness to criticise chunks of private law that are inexplicable in terms of corrective justice. Weinrib writes that one of the principal goals of one of his more recent monographs is "to criticize examples of legal doctrine that fail to adhere to the corrective justice structure": Weinrib, supra note 92, 3. Weinrib commits himself here to the proposition that private law should be explicable in terms of corrective justice. It is irrelevant for present purposes that Weinrib has made prescriptive claims in this subsequent work. This is because this article is concerned with his explanatory theory of tort law (for passages in which Weinrib explicitly states to be advancing such a theory, see the text accompanying supra notes 1-8), and explanatory theories draw no support from prescriptive claims about what the law ought to be: see supra Part IIB2. Even if Weinrib were to abandon completely his explanatory theory in favour of a wholly prescriptive theory, that too would also be of no particular consequence for present purpose for the reasons given in supra note 28. 
lengths to establish this at the outset of our analysis. ${ }^{212}$ We have done nothing more than question whether the theorists have succeeded in their endeavour. Secondly, we doubt that there is any material difference between explanatory theories and interpretive theories. Both types of theoretical accounts endeavour, ultimately, to search out meaning in the law. We observe that none of the theorists with whose work we engage relies on the postulated distinction between explanatory and interpretive theories. They may well regard that distinction being employed in aid of their theories as a disservice. Thirdly, even if there is a material difference between explanatory and interpretative theories, it is widely agreed that an important criterion for measuring the success of an interpretative theory is fit with the thing that theory seeks to explains. Ronald Dworkin, a pioneer in this regard, insisted that the first requirement of "any interpretation of any material" is that "it must fit that material". ${ }^{213}$ Allan Beever and Stephen Smith - who have undertaken important theoretical studies of the law of negligence and the law of contract respectively - similarly have declared the significance of fit to interpretative theories. $^{214}$

(4) Are the theories really universal theories? It might be doubted whether, in asking if the theories in question are satisfactory universal theories of tort law, we have judged the theories against a standard which their authors never intended them to meet. Any such doubt would be unwarranted. We have shown at considerable length above that it is entirely appropriate to regard the authors of the theorists are offering universal accounts of tort law. ${ }^{215}$ Some of the theorists expressly indicate that the theorists are intended to be universal in their scope. Even if were inappropriate to read the theorists in the way

\footnotetext{
${ }^{212}$ In the case of Weinrib, see the text accompanying supra notes 5-8, in relation to Stevens, see the text accompanying supra note 11 , and with respect to Posner see the text accompanying supra note 15.

213 Ronald Dworkin, Law's Ambitions for Itself, 71 Va. L. Rev. 173, 177 (1985).

214 Stephen Smith, Contract Theory (2003) 7-11; Beever, supra note 18, 21.

215 See Part I supra.
} 
that we do, this would be irrelevant, for it would still be worthwhile to determine whether the theories that they promote account satisfactorily for the law in most than one jurisdiction.

(5) Are the theories impervious to objections based on a lack of fit with the law? A further objection that might be pressed is that the theories in question are immune to being criticized on the grounds that they do not fit the law. Murmurings, and arguably more than that, can be found in the literature to this effect. ${ }^{216}$ Such an objection would go nowhere. A theory that purports to explain something, including the law, fails to the extent that it does not explain the thing in question, at least if the mismatch between the theory and the thing is sufficiently great. Cane puts this point as follows: "[T]here must come a point where gaps between the explanandum and the explanans cast doubt on the value of the explanation ... [and in the realm of tort theory this matters] because many private-law theorists aim primarily for explanatory power”. ${ }^{217}$ Our article has employed this entirely conventional mode of legal reasoning. Indeed, it is precisely the same mode of reasoning that is employed by our target theorists. As we have noted in fending off the Objection (3), the very scholars who have proposed the universal theories of tort law in question are fundamentally concerned to show that their theory fits the law, and they all contend that rival theories provide a poorer fit. We consider the suggestion that a theory that purports to explain something is immune to being challenged on the ground that it does not explain the thing in question to be self-evidently untenable. It might be said that we have not identified the precise point at which a lack of fit becomes objectionable. This is true but it is unnecessary for us to isolate a specific moment at

\footnotetext{
${ }^{216}$ See, e.g., Weinrib, supra note 19, at 291 (suggesting that divergence between tort law and corrective justice presents no difficulty for his corrective justice theory of tort law); Beever, supra note 18, at 25 (contending that fit is just one of several criteria for judging a theory, and thereby suggesting that a lack of fit might not be problematic).

${ }^{217}$ Peter Cane, The Anatomy of Private Law Theory: A 25 $5^{\text {th }}$ Anniversary Essay, 25 OJLS 203, 207 (2005).
} 
which a want to fit becomes problematic. Given that our target theorists ultimately are concerned to show that their theories conform to the law, a significant problem of fit is something that necessarily causes difficulty for their respective theories. We have developed an extremely demanding test for significance and have discussed only problems of fit that satisfy this (probably excessively exacting) threshold.

(6) Has the analysis not merely pointed out that there are inter-jurisdictional differences in tort law? Any suggestion that this article has simply trawled through differences in the law of torts between the major common law jurisdictions would reveal a fundamental misunderstanding of it. This suggestion also betrays profound confusion about the ways in which explanatory theories of the law justifiably can be criticised. We sought to head off such possible misunderstandings at an early stage. ${ }^{218}$ But some of the points that were made earlier bear re-emphasising. The aim of the article emphatically has not been to note differences in the law of torts across the common law world. Its goal, rather, has been to demonstrate that the universal theories of tort law on offer fail qua universal theories. This goal cannot be achieved simply by pointing to differences in tort law between jurisdictions. This partly is because a given theory might be able to accommodate different rules on a given point. In other words, more than one rule applicable to a given factual situation might be compatible with a certain theory. It follows that merely pointing to differences in the law between jurisdictions would not have taken the analysis anywhere, and this, hence, is not what we have set out to do. Rather, we have noted aspects of the law across jurisdictions that are incompatible with the theories under consideration. It just so happens that these incompatibilities are frequently the product of differences in the law. But such differences only are important for present purposes if they are left unexplained.

\footnotetext{
${ }^{218}$ See the introductory paragraphs of Part III supra.
} 
It is important to understand in this connection that similarities in the law between jurisdictions can just as easily present a problem for the theories under consideration as differences in the law. Suppose, for example, that all four jurisdictions with which this article is concerned adopted rule $\varphi$ and that theory $\Phi$ was unable to account for that rule. That failure would be evidence that theory $\Phi$ is an unsatisfactory universal theory of tort law. It matters not one iota that the failure is not a consequence of any differences in the law. We have, of course, utilised this logic in developing our argument throughout this article. That is to say, we have frequently argued that more than one jurisdiction embraces rule $\varphi$, that theory $\Phi$ cannot explain that rule, and that that failure therefore counts against the theory qua universal theory. To give just one example, we have pointed to the fact that the rule in Rylands $v$ Fletcher, which is materially the same in Canada, the United Kingdom and the United States, is incompatible with Weinrib's corrective justice theory. ${ }^{219}$ The fact that similarities in the law between the jurisdictions in question can equally present problems of fit for the theories, and the fact that this article has often referred used similarities in the law between the jurisdictions in developing the argument serves to emphasise that this article is not simply a search for differences in the law between jurisdictions.

(7) If the article's core claims are valid, has the article failed to indicate what tort theorists should be doing? It might be complained that we have not revealed our hand as to whether or not we think that it is possible to devise a satisfactory universal theory. It is impossible for us to prove a negative, that is to say, that there cannot be a satisfactory universal theory. However, we consider it to be extremely unlikely that such a theory could be devised, partly because of the demise of the view that there is a single common law throughout the world and the resulting diversity within the law of torts inter-

\footnotetext{
219 See Part IIE2 supra.
} 
jurisdictionally. ${ }^{220}$ What does this mean we think tort theorists should be doing? It is neither necessary nor, within the space available to us, possible, to give an adequate answer to this question. Doing so would take us far beyond the stated scope of this article. However, very briefly, our hope is that theorists will offer more nuanced theoretical accounts of tort law, or perhaps just parts of it, and that they will be more candid about the things that they are unable to explain.

220 The demise of that theory is discussed in Anthony Mason, Future Directions in Australian Law, 13 Monash University Law Review 149 (1987); Robin Cooke, The New Zealand National Legal Identity, 3 Canterbury L. Rev. 171 (1987); W.S. Clarke, The Privy Council, Politics and Precedent in the Asia Pacific Region, 39 ICLQ 741 (1990); Robert Sharpe \& Kent Roach, Brian Dickson: A Judge's Journey 317-320 (2003). 